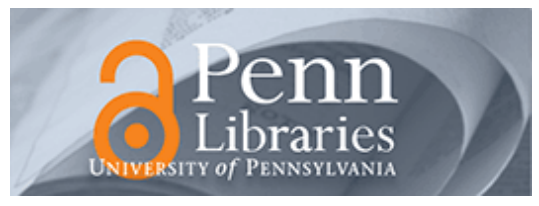

University of Pennsylvania

ScholarlyCommons

Accounting Papers

Wharton Faculty Research

$9-2001$

\title{
The Relevance of the Value-Relevance Literature for Financial Accounting Standard Setting
}

Robert W. Holthausen

University of Pennsylvania

Ross L. Watts

Follow this and additional works at: https://repository.upenn.edu/accounting_papers

Part of the Accounting Commons

\section{Recommended Citation}

Holthausen, R. W., \& Watts, R. L. (2001). The Relevance of the Value-Relevance Literature for Financial Accounting Standard Setting. Journal of Accounting and Economics, 31 (1-3), 3-75. http://dx.doi.org/ 10.1016/S0165-4101(01)00029-5

This paper is posted at ScholarlyCommons. https://repository.upenn.edu/accounting_papers/122

For more information, please contact repository@pobox.upenn.edu. 


\title{
The Relevance of the Value-Relevance Literature for Financial Accounting Standard Setting
}

\begin{abstract}
In this paper we critically evaluate the standard-setting inferences that can be drawn from value relevance research studies that are motivated by standard setting. Our evaluation concentrates on the theories of accounting, standard setting and valuation that underlie those inferences. Unless those underlying theories are descriptive of accounting, standard setting and valuation, the value-relevance literature's reported associations between accounting numbers and common equity valuations have limited implications or inferences for standard setting; they are mere associations. We argue that the underlying theories are not descriptive and hence drawing standard-setting inferences is difficult.
\end{abstract}

\section{Keywords}

accounting theory, standard setting, value relevance, valuation

Disciplines

Accounting 


\title{
The Relevance of the Value Relevance Literature For Financial Accounting Standard Setting
}

\author{
Robert W. Holthausen \\ The Wharton School \\ University Pennsylvania \\ Ross L. Watts \\ William E. Simon Graduate School of Business Administration \\ University of Rochester
}

First draft: November 14, 1999

Current draft: September 22, 2000

\section{COMMENTS WELCOME}

This paper was prepared for the Journal of Accounting \& Economics Conference held April 28-29, 2000. We wish to thank Kirsten Ely, Rick Lambert, Fred Lindahl, Greg Waymire, the discussants (Mary Barth, Bill Beaver and Wayne Landsman), the editors (S.P. Kothari, Tom Lys and Jerry Zimmerman) and workshop participants at George Washington University, M.I.T. and the Journal of Accounting \& Economics Conference for their helpful comments. 


\title{
The Relevance of the Value Relevance Literature For Financial Accounting Standard Setting
}

\begin{abstract}
We evaluate the literature that, for standard-setting purposes, assesses the usefulness of accounting numbers on their stock market value association. For several reasons we conclude the literature provides little insight for standard setting. First, the association criterion has no theory of accounting or standard setting supporting it. Standard setters' descriptions of their objectives and accounting practice are both inconsistent with the criterion. Important forces shaping accounting standards and practice are ignored. Second, many tests in the literature rely on valuation models that omit important factors and many studies do not provide links between valuation model inputs and accounting numbers. Finally, there are a variety of significant econometric issues in the studies.
\end{abstract}




\section{Introduction}

Over the last decade a large number of accounting papers investigate the empirical relation between stock market values (or changes in values) and particular accounting numbers for the purpose of assessing or providing a basis of assessing those numbers' use or proposed use in an accounting standard. We call the group of papers that are at least partially motivated by standard setting purposes, the "value-relevance" literature. This paper's objective is to critically evaluate the standard-setting inferences that can be drawn from these value-relevance papers. The evaluation provides suggestions for future research for standard setting purposes.

A number of papers raise issues about the methodology used in the valuerelevance literature, particularly econometric issues (e.g., Lambert, 1996; Lys, 1996; and Skinner, 1996, 1999). While we address econometric issues in this paper, we concentrate more on the logic and assumptions underlying the standard setting implications of the value-relevance papers. The logic and assumptions imply theories of standard-setting, accounting and valuation. Assessing the papers' implications for standard-setting requires evaluating the descriptiveness of those theories. Moreover, an understanding of these issues is necessary to address econometric issues.

There are other papers in the accounting literature that address the valuerelevance of accounting information without regard to standard setting. For example, the capital markets literature in accounting provides evidence on topics such as the information content of accounting numbers and the determinants of earnings response coefficients. That literature is reviewed in detail in Kothari (2001). While we don't review that literature directly, our assessments of the valuation models and the assumed links between the accounting numbers and the valuation models (section 5) are directly applicable to those papers in the capital markets literature that rely on the same models.

Other accounting papers address reasons various parties to standard-setting (for example, management) prefer particular accounting method alternatives. Evidence from those papers is directly relevant to developing theories of accounting and standard setting of the type we discuss in sections 3 and 4. However, the theories of accounting and standard setting underlying value-relevance studies generally do not incorporate factors 
other than association with value. ${ }^{1}$ Moreover, studies of management preferences among accounting alternatives are part of the literature reviewed in Fields, Lys and Vincent (2001). For these reasons we do not review that literature in this paper.

\section{$1.1 \quad$ Types of studies}

To facilitate our analysis we classify the value-relevance studies into three categories. Other papers use a similar classification (e.g., Lambert, 1996). Some individual papers fall into several categories of studies.

i) Relative association studies compare the association between stock market values (or changes in values) and alternative bottom line measures. For example, a study might examine whether the association of an earnings number, calculated under a proposed standard, is more highly associated with stock market values or returns (over long windows) than earnings calculated under existing GAAP (e.g., Dhaliwal, Subramanyam and Trezevant, 1999). Other examples compare the associations of foreign GAAP and US GAAP earnings (e.g., Harris, Lang and Moller, 1994). These studies usually test for differences in the $\mathrm{R}^{2}$ of regressions using different bottom line accounting numbers. The accounting number with the greater $\mathrm{R}^{2}$ is described as being more value-relevant. Table 1 provides a partial listing of papers in the value-relevance literature classified by type of study performed. Fifteen ( 24 percent) of the 62 papers listed in Table 1 perform a relative association study.

ii) Incremental association studies usually use regressions to investigate whether the accounting number of interest is helpful in explaining value or returns (over long windows) given other specified variables. That accounting number is typically deemed to be value relevant if its estimated regression coefficient is significantly different from zero. For example, Venkatachalam (1996) examines the incremental association of the fair value of risk management derivatives disclosed under SFAS 119 in a

\footnotetext{
${ }^{1}$ One of the papers listed in Table 1, Aboody and Lev (1998), investigates both value-relevance and management preferences. That paper does not, however, include management preferences as a standard
} 
regression of equity market value on a variety of on and off balance sheet items. Some incremental association studies make additional assumptions about the relation between accounting numbers and inputs to a market valuation model in order to predict coefficient values and/or to assess differences in the error with which different accounting numbers measure a valuation input variable. For example, Venkatachalam (1996) also tests whether the coefficient on the fair value of derivatives is significantly different from one. Differences between the estimated and predicted values are often interpreted as evidence of measurement error in the accounting number. For that reason we call those studies measurement studies. Fiftythree ( 85 percent) of the 62 papers in Table 1 perform an incremental association study. Thirteen ( 25 percent) of the 53 papers perform measurement studies.

iii) Marginal information content studies investigate whether a particular accounting number adds to the information set available to investors. They typically use event studies (short window return studies) to determine if the release of an accounting number (conditional on other information released) is associated with value changes. Price reactions would be considered evidence of value-relevance. For example, Amir, Harris and Venuti (1993) test the marginal information content of the Form 20-F reconciliation of foreign and US GAAP earnings numbers for foreign firms by regressing five-day abnormal announcement returns on the difference and the change in the difference between foreign and US GAAP earnings. Only seven (11 percent) of the 62 papers perform an information content study.

Given 94 percent of value-relevance papers perform association studies (relative and/or incremental) while only 11 percent perform information content studies and that marginal information content is probably not necessary nor sufficient for standard-setting (see section 3), we concentrate on association studies. Holthausen and Palepu (1994) contains an extensive review of marginal information content studies. 


\subsection{Standard-setting motivation}

We rely on statements in the papers to assess whether the authors view their results as having implications for standard setting. Papers that explicitly state that their results have such implications are included in the literature and listed in Table 1. We find 54 such papers. We also include in Table 1 a small number of papers (eight) whose language implies (but does not explicitly state) standard setting implications. This latter determination is necessarily subjective. Note that standard setting is not necessarily the sole motivation of the papers listed in Table 1 since many also contribute to the accounting valuation literature.

We quote four papers as examples of the types of statements made in this literature. The first three examples have explicit standard-setting motivations (Ayers, 1998; Barth, 1994; and Dhaliwal et al, 1999), while the fourth (Amir and Lev, 1996) is an example of a more implicit standard setting motivation. Ayers (1998, p. 196) motivates his incremental association study as follows:

". . .the question of whether SFAS No. 109 provides incremental valuerelevant firm specific information is of interest for at least two related reasons. First, the FASB is obligated to consider the costs and benefits of its standards ... Second, the objective of accounting policy decisions is to produce information that is relevant and reliable (FASB 1980, SFAC No.2)."

The motivation for Barth's (1994, p. 1) incremental association study is also explicit:

"By examining how share prices reflect historical costs and fair values, evidence is provided on the measures' relevance and reliability. Because these are the FASB's two principal criteria for choosing among accounting alternatives ... the evidence can inform the FASB's deliberations on using fair value accounting for investment securities, to the extent the disclosed fair value estimates would be used to measure investment securities under fair value accounting."

Dhaliwal et al (1999, pp. 44-47) provide explicit standard setting motivation for their relative association study:

"SFAS 130 is the culmination of a long-standing debate in the accounting profession between the 'all-inclusive' (or 'comprehensive income') and the 'current operating performance' concepts of reporting income. This debate has been at the forefront of accounting-standard setting from the 
1930s to the present. ... This analysis allows us to draw inferences regarding the appropriateness of current and potential items of comprehensive income. These inferences should assist the Financial Accounting Standards Board as it turns to the broader-scope projects (described in SFAS 130, paragraph 54) that will address the issue of which items should be included in "other comprehensive income."

In our view, the above quoted papers and the others listed in Table 1 as explicitly motivated by standard setting, contain direct statements of their standard setting motivations. Occasionally, however, the standard-setting motivation is implicit. For example, Amir and Lev (1996, p. 28) state in their conclusion:

"The evidence presented in this study indicates that current financial reporting of wireless communications companies - a large world-wide and technologically leading industry - is inadequate. Specifically, significant value-enhancing investments in the cellular franchise and in expanding the customer-base are fully expensed in financial reports, leading to distorted values of earnings and assets."

In this quote the description of current financial reporting as "inadequate" and generating "distorted" values suggests that reporting should be improved, presumably via new accounting standards. In particular, Amir and Lev (p. 5) suggest capitalization of customer-acquisition costs in the financial statements or "clear separation between regular expenses and costs which potentially enhance future cash flows ..."

\subsection{Theories underlying studies and inferences for standard-setting}

Drawing standard setting inferences from the results of a value-relevance study requires theories of standard setting, accounting and valuation. This may not be immediately obvious from many value-relevance papers, because they do not always fully articulate those theories. Some authors, however, are quite explicit in laying out the required links necessary to draw any implications for standard setting.

The nature of implicit standard setting theories underlying value-relevance papers' inferences can be gleaned from the experimental designs in the papers. For example, as quoted earlier, Dhaliwal et al (1999) draw inferences regarding the relative superiority of two alternative summary measures of income by assessing those measures' 
association with stock returns. ${ }^{2}$ This implies that the association between an accounting number and value is a factor in standard setters' decisions on the specification of accounting income. This contrasts with Barth (1994) who is explicit about the standard setters' decision criteria. Based on Statement of Financial Accounting Concepts (SFAC) No.2 she assumes the FASB's two prime criteria for choosing among accounting measures are those measures' relevance and reliability. While her measures of relevance and reliability are based on associations with value, she does not assume that the associations themselves are of direct interest to standard setters.

Value-relevance papers also rely on accounting theories. In particular, in drawing inferences for standard setting, most authors assume that accounting's dominant role (from a standard setter's perspective) is to provide information relevant for equity valuation (see Barth, 2000; and Lambert, 1996). Other accounting functions may be recognized, but they are not explicitly considered in the research design.

Finally, valuation models or theories underlie some value-relevance papers' standard setting inferences. For example, the experimental design in Barth (1994) requires specific valuation models in order to generate estimates of the relevance and reliability of fair values of investment securities from the association between accounting numbers and stock prices.

The potential to draw standard setting inferences from value-relevance papers' results depends on the descriptiveness of the underlying theories of standard setting, accounting and valuation. The less descriptive the theories, the less likely standard setting inferences are valid. To illustrate the importance of the descriptive ability of the underlying standard setting theory, consider the two examples given above. The less the FASB relies on an income measure's association with stock returns in setting accounting standards, the less reliable are Dhaliwal et al's implications for the composition of accounting income measures. If the concepts of relevance and reliability employed by Barth do not match the concepts of relevance and reliability as used by the FASB, then any inferences drawn about the relevance and reliability of the fair value estimates of investment securities in those tests are subject to question. Since it is not obvious that the

\footnotetext{
${ }^{2}$ As a specification check, Dhaliwal et al (1999) also examine the associations between comprehensive income and net income with operating cash flows and net income measured one-year ahead. Those results
} 
underlying standard setting theories are descriptively accurate, assessment of the potential of the value-relevance literature to inform standard setting requires a determination of the descriptive ability of the underlying standard setting theory.

Standard setting inferences also depend on the underlying accounting theory's descriptive ability. It is not obvious that standard setters consider equity valuation to be the sole or dominant function of accounting reports. There are other well-recognized functions of accounting (private contracting with its associated monitoring, regulation, litigation, etc.) and there is ample evidence to suggest that they influence standard setting. Assessment of the value-relevance's implications for standard setting requires a determination of the descriptive ability of the underlying accounting theory.

The valuation models employed in the value-relevance literature (like all valuation models and theories) necessarily incorporate a number of assumptions that are not descriptive. A theory is necessarily a simplified model of the world. However, some of the valuation model assumptions employed seem likely to make those models significantly less descriptive, which potentially affects the validity of any standard setting inferences that could be drawn from those results. For example, the valuation models used in the value-relevance literature frequently assume that firms do not earn rents, so that the market value of equity is equal to the market value of net assets. That enables papers to predict significant positive (negative) coefficients on measures of individual assets (liabilities), predict the magnitude of the coefficients (under certain assumptions) and estimate a linear valuation equation. However the existence of rents (and abandonment and expansion options) is likely, implying a non-linear valuation equation. In that case estimation using a linear model could generate coefficients different from those predicted. The descriptive ability of the valuation theory, like the descriptive validity of the standard setting and accounting theories is important.

Note that in looking to equity market values to determine relevance, the value relevance literature assumes capital markets are efficient (e.g., equity prices containing unbiased estimates of the market values of assets and liabilities). There is a significant body of literature that questions the efficiency of capital markets (see Kothari, 2001). Some studies make even stronger assumptions than market efficiency: the market's 
estimates are assumed not just to be unbiased but instead to be error-free (prices are not noisy).

Because many value-relevance studies do not articulate the theories underlying their tests and inferences, the links between the theories and accounting are not often well specified. For example, rarely is the link between the accounting measure (coming out of some accounting theory) and a valuation variable (from a valuation model or theory) well specified. Studies often employ valuation models that express the market value of equity as some multiple of permanent earnings and then substitute current earnings for permanent earnings without explaining the relation between the accounting measure and the valuation model input. These ill-specified links also likely reduce the descriptive ability of the theories and weaken any potential standard setting inferences.

Given the importance of the descriptive ability of the theories underlying the value-relevance literature, we investigate the theories' empirical implications and conclude that the theories are not very descriptive. This raises questions regarding the appropriate inferences that can be drawn from this literature and the ability of the literature to inform standard setting. We also explore avenues of research that we believe would yield additional insights about standard setting and the role of accounting.

While not our primary focus, many of the issues we discuss in this paper are important to empirical work in the capital markets literature in general, for example valuation research using accounting measures. As such, some of the comments here can be viewed as a critique of elements of that literature as well, particularly the discussion of the assumed valuation models and the links between the accounting numbers and the models' required inputs. What makes the value-relevance literature different from most of the general capital markets literature, are the value-relevance literature's underlying theories of standard-setting and accounting. In addition, not all of the capital markets literature, as it is generally defined, relies on the valuation models discussed here.

\subsection{Outline of the paper}

Section 2 examines value relevance papers' stated explanations of the logic and assumptions underlying their empirical tests and the assumptions implicit in the empirical tests themselves in order to infer underlying theories of accounting and standard setting. 
Those papers often base some of their stated assumptions about standard-setting and the role of accounting on FASB statements. In Section 3 it is noted that the role of accounting implicit in a consistent application of the value relevance tests, valuation of equity securities, is explicitly contradicted by SFAC No.1. This suggests problems with the assumptions and logic underlying the tests' derivation. Three assumptions are identified as not following from FASB statements. We conclude that the value-relevance tests omit some factors that the FASB states are important for assessing whether information is useful and use some criteria that are contrary to FASB statements.

In the fourth section, we investigate whether the explicit and implicit standard setting and accounting theories used in the value-relevance literature can explain observed accounting practice. The objective is to provide evidence on the descriptive ability of the literature's underlying theories of standard setting and accounting. We identify some important characteristics of current accounting practice (for example conservatism) that are not explained by the criteria used in the value-relevance literature. This raises questions about the literature's underlying theories of standard setting and accounting, for example the dominance of the valuation use of accounting numbers. We discuss a number of uses of accounting reports, extant in the more general accounting literature, that have the potential to explain characteristics of observed practice. This is important because it indicates that the value-relevance literature alone is not likely to be very informative to the standard setting community.

Section 5 evaluates the valuation models used in value-relevance empirical studies and the links between accounting numbers and valuation model inputs. We find the three basic valuation models used in the literature are appropriate only under very restrictive circumstances and that none of them can adequately deal with growth and abandonment options. It is also important to note that none of the valuation models provide any role for accounting. For example, two of the models typically used provide no role for components of earnings. This lack of a role for accounting makes their use in assessing the desirability of alternative accounting constructs problematic.

Finally, section 6 offers our conclusions and suggestions for future research. The main conclusion is that value-relevance tests do not incorporate, and in some instances conflict with, a variety of considerations involved in standard setting and the role of 
accounting. In other words, the theories of standard setting and accounting underlying the value-relevance literature are not descriptive. This determination is based on both statements of the FASB and observed practice. Even if the theories of standard-setting underlying the value-relevance literature were completely consistent with FASB statements about standard setting, the literature would still fail to meet its objectives due to deficiencies in the valuation models used. Many authors in this literature offer appropriate caveats for some of these problems. But, what is not often made clear is that the criteria underlying the value-relevance literature are quite narrow in scope, relative to the multiple uses of financial statements and so are unlikely to be very informative to the standard setting community.

Our discussion suggests a variety of researchable issues that could help inform standard setting. One is that accounting researchers investigate the existence and strength of forces, other than equity valuation, that affect accounting standards and practice. A more thorough understanding of those forces would make our research more useful to standard setters. An understanding of those forces is also important to the accounting valuation literature.

\section{The Underlying Logic and Assumptions}

Value-relevance papers vary in the depth of their explanations of the logic and assumptions underlying the links between their methodology and standard-setting, ranging from minimal or no explanation to relatively complete explanations. The logic and assumptions essentially embody theories of standard setting, accounting and valuation. Below we give an example of each of the extremes of explanation, recognizing that many papers fall between these benchmarks.

Minimal or no explanation. Many value-relevance studies provide minimal explanation of the logic and assumptions underlying their methodology. Some rely on references to more complete explanations in papers such as Barth $(1991,1994)$, one of which is discussed below. Others, many of them relative association studies, do not reference more complete explanations, nor do they provide their own logic or support for their assumptions. Dhaliwal et al (1999) is an example. Additional examples include, 
among others, Alford, Jones, Leftwich and Zmijewski (1993), Harris, Lang and Moller (1994) and Harris and Muller (1999).

Dhaliwal et al (1999) assess whether net income or comprehensive income is a better measure of firm performance by comparing the two measures' associations with stock returns. The paper's motivation (quoted previously) and its stated implications (pp. 60-61) assume accounting standard-setters are interested in which income measure is most highly associated with stock market value changes. No evidence that standardsetters have such interest is given or referenced in the paper, and no rationale for why they would be interested in the results of relative association tests is discussed in the paper.

Presumably Dhaliwal et al's rationale for comparing the explanatory power of income numbers is that the one with the highest association is more consistent with the information investors use in setting stock prices (see Lambert , 1996, p. 19). This conclusion is derived from the theory underlying many value-relevance studies that views accounting as supplying inputs to equity valuation (see Lambert, 1996; and Barth, 2000). Investors can use the estimated relation between stock prices and income to obtain an estimate of the equity value from the income number that is most highly associated. Note that the mostly highly associated income number is not necessarily the most accurate measure of equity value. To illustrate, assume net income is intended to measure permanent income (a perpetuity whose value equals the value of equity) and stock price/income regressions are estimated for each alternative net income measure. Then the most accurate measure is the income number whose regression yields an estimated intercept of zero and an estimated slope coefficient of one over the discount rate (see Lambert, 1996, pp. 19-26). The income measure most associated with stock price could be one with an estimated intercept significantly different from zero and an estimated slope coefficient significantly different from one over the discount rate. An estimate of equity value could be obtained from the most associated income number by using the estimated regression. ${ }^{3}$ Choosing between the accuracy and association criteria requires

\footnotetext{
${ }^{3}$ For example, suppose the $\mathrm{R}^{2}$ of a regression using earnings series 1 is $40 \%$, the intercept is $-55,001$ and the slope coefficient is 25.25 . For earnings series 2 , assume the $\mathrm{R}^{2}$ of the series is $36 \%$, the intercept is zero and the slope coefficient is 10 , exactly equal to the predicted value of the coefficient of permanent income, one over the discount rate (10\%). Furthermore, assume the $4 \%$ difference in the $\mathrm{R}^{2}$ is statistically
} 
an accounting and standard setting theory. If the FASB is interested in investors being able to use the information to generate their own estimates of value, association is the appropriate test. If the FASB is interested in income measuring value, accuracy might be the appropriate test. Without a theory of accounting and standard setting, one cannot determine which is the appropriate criterion.

Pursuing the objective of maximizing association would lead to income being highly associated with value or changes in value. While this is motivated by an input to valuation argument, it will in practice lead to an income number that is a linear transformation of value itself. This hardly seems consistent with an input to valuation view of accounting. Dhaliwal et al argue they are merely testing claims of various parties who argue over whether net income or comprehensive income is a better summary measure of performance. But, as indicated above, is a "better summary measure of performance" one that more accurately measures permanent income or one that is more highly associated with changes in value? They judge the quality of alternative summary measures primarily by mere association with changes in equity value. Note that the reliance on aggregate changes in value means Dhaliwal et al do not have to specify a valuation model.

Relatively complete explanation. Some of the incremental association studies have more complete explanations of their underlying logic and assumptions, though again there are large differences across studies. Many, as suggested in the earlier Ayers quote, link an accounting measure's incremental value-relevance to the concepts of relevance and reliability, which are explicitly discussed by the FASB as being important characteristics of accounting information.

The Barth (1994) incremental association study provides one of the most complete explanations for the logic and assumptions underlying a value-relevance study. As we have noted, Barth's underlying standard setting theory relies on standard-setters' statements about the criteria for choice among accounting alternatives. In particular,

significantly at the $5 \%$ level. How would the FASB consider the tradeoff of explanatory power versus accuracy? Earnings series 1 clearly has the greater explanatory power and would be pronounced "the winner" in a relative association test study. In order to estimate equity value from earnings series 1 , one would scale the earnings series by an appropriate factor and adjust for the intercept. Earnings series 2, despite its slightly lower explanatory power, closely approximates permanent income and estimated value is the earnings multiplied by 10 . 
based on SFAC No.2, she assumes the FASB's two prime criteria for choosing among accounting alternatives are the comparative relevance and reliability of the alternative measures. Her objective in the paper is to compare the relevance and reliability of fair market value and historical cost measures of the value and change in value of investment securities held by banks. Barth (2000,p.16) states that "relevance refers to the ability of the item to make a difference to decisions of financial statement users" and "reliability refers to the ability of the measure to represent what it purports to represent." The relevance definition is consistent with SFAC No.2 paragraph 47 . The reliability definition is roughly consistent with SFAC No.2 paragraph 59 except that it makes no mention of verification. Paragraph 59 states "the reliability of a measure rests on the faithfulness with which it represents what it purports to represent, coupled with an assurance for the user, which comes through verification , that it has representational quality." As we shall see verifiability can be important and might not be reflected in incremental association.

The links articulated in Barth (1994) including the measurement error model of Section V (pp. 20 - 23) employs a variation of the methodology in Barth (1991) that is found in varying degrees in other value-relevance papers. A comparison of the differences in the relevance and reliability of different accounting measures requires a benchmark of the variable being measured, the "true" value of investment securities and the true gain and loss on those securities. To achieve this, Barth uses the asset value of investment securities implicit in the stock price: "The approach views accounting measures as variables measured with error and the amounts implicit in share prices as 'true' variables." (Barth, 1994, p. 20). The assumption that the amounts in share prices are the "true" variables is stronger than market efficiency: the market's estimates are not just unbiased they error-free. The comparison of accounting numbers to variables implicit in stock prices implies accounting provides measures of variables that are inputs to valuation.

Comparison of "true" asset values implicit in share prices with accounting measures of those values requires the assumption of a particular stock market valuation model. Barth assumes three stock market valuation models; one for the market value of equity used in evaluating the relevance and reliability of measures of the asset's value, 
and two for changes in value or stock returns used in evaluating changes in the asset's value. In all the valuation models, the "true" value of the investment securities is the asset's market value implicit in the market value of the equity.

Barth uses a variety of regression specifications to simultaneously determine the "true value" of the investment securities implicit in price as well as to assess the relevance and reliability of the alternative accounting measures. To illustrate Barth's logic with minimal investment and no loss of explanatory power, we use only one of her specifications. The specification includes a single accounting measure of the value of investment securities, fair value. In that specification, stock market values are regressed on investment securities' fair value and the book value of equity before investment securities. The same model is also run where historical cost measures of investment securities are substituted for the fair value measures.

The relevance and reliability of a fair value measure are inferred from the significance of the fair value measure's estimated regression coefficient. Based on her assumed valuation models, Barth argues (p. 7) the estimated coefficient on the fair value of investment securities should be one. As Barth recognizes, this requires; (1) the valuation models be correct; (2) all the accounting measures equal the value of their relevant variables in the valuation models (there is no measurement error or bias); and (3) the measures of all the variables in the valuation models be included (no correlated omitted variables). If fair value measures the asset's market value with sufficient error or bias, the estimated coefficient could be other than one and potentially insignificant.

Barth argues that a significant incremental association with the implicit market value of investment securities indicates the fair value of investment securities is used as an estimate of an input into an equity valuation model, which in turn implies it is relevant to some business decisions. The finding that the measurement error is insufficient to generate insignificance suggests that the measure is at least somewhat reliable. ${ }^{4}$

\footnotetext{
${ }^{4}$ These conclusions assume there are no correlated omitted variables and that the accounting measures of assets and liabilities other than non-investment securities have no measurement error . Barth recognizes that, if some valuation variables are omitted from the regression, the significance of the fair value measure's coefficient could be due to correlation between the fair value measure and the omitted variables rather than to the relevance and reliability of the fair value measure. She also allows for measurement error in the historical cost and fair value variables in her tests, by imposing a specific structure for the measurement error. In addition, she attemp ts to discriminate between a measurement error and correlated omitted variables explanation for her finding that the fair values of assets are highly correlated with the
} 
The discussion of the Barth (1994) paper clearly demonstrates the theories and assumptions necessary to draw standard setting inferences from her tests. Among the necessary conditions for drawing any type of inference on whether the fair value of investment securities should be included in the balance sheet are the following. First, any inference requires the FASB be concerned about the extent to which investment securities' fair value estimates measure their "true" market values (e.g. the extent of bias and measurement error) as a precondition for recognition in the balance sheet. Thus, implicit here is a theory of standard setting and the role of accounting. Second, it requires the market valuation model be descriptive (e.g., in the levels model, it is assumed that the market value of equity approximately equals the market value of the separable net assets). Thus, this presumes the valuation model is appropriate and observed equity prices are not very noisy estimates of "true value" of the common equity. Third, it requires the book value of net assets (other than investment securities) measure the market value of those net assets without bias and or measurement error (or that somehow, the tests control for those problems). Fourth, it requires no correlated omitted variables.

Between the extremes of the Dhaliwal et al (1999) and the Barth (1994) papers lie a wide range of explanations of the standard setting and accounting theories underlying the associations estimated and the standard setting inferences generated. Regardless of the completeness of their explanation, all of the value-relevance papers assume the primary purpose of financial reporting (financial statements and disclosures) is to provide information to investors for use in assessing the value of the firm for investment decision purposes. This assumption seems to be made both as a description of accounting practice as part of an accounting theory and as a description of the objective pursued by accounting standard setters as part of a standard setting theory. Barth (2000, p. 10) states "Investors represent a large class of financial statement users and thus much academic research addressing financial reporting issues relevant to practicing accountants, particularly standard setters, adopts an investor perspective ... investors are primarily 
interested in information that can help them assess the value of the firm for purposes of making informed investment choices."

Value-relevance studies determine whether an accounting number is useful for valuing the firm by investigating whether the accounting number is associated with stock prices. As we have seen, relative association studies test the relative usefulness of alternative financial statement bottom line numbers. Incremental association studies test the usefulness of individual financial statement components or disclosures. As noted in discussing the Dhaliwhal et al explanation, the relative association test implies that income numbers can be transformed into estimates of the equity value or change in value. Incremental association study tests are supposed to indicate the usefulness of accounting measures as inputs to valuation. However, the distinction between the two interpretations is more cosmetic than real. To see this consider what would happen if the FASB literally followed the standard setting inferences made from incremental association studies and did not consider any other factors.

Consider studies involving balance sheet components and using the balance sheet valuation model described in Barth (1994) (i.e., the market value of equity equals the market value of net assets). Assume the incremental studies solve all the problems identified earlier: the valuation model is descriptive, the problems of bias and measurement error in the variables are controlled and there are no correlated omitted variables. Suppose the FASB embarked on a program of conducting incremental association studies on all assets and liabilities one at a time. ${ }^{5}$ First, assume they select the accounting measure for each asset or liability that has the highest incremental association with equity market value. If the program were successful the net asset value would be

\footnotetext{
${ }^{5}$ The value relevance literature seems to be expanding to cover a wide range of assets, liabilities and earnings components. It is not restricted to assets such as investment securities where the circumstances are more suitable for studies such as Barth (1994). Nine of the papers listed in Table 1 study investment securities, but 57 papers study other accounting topics (the numbers add to more than 62 because some papers study multiple accounting topics). The numbers of studies on various issues are: eight on intangible assets (including software development, brand names, development expense, goodwill, patents and research and development); five on other asset valuation (current cost, property, oil and gas reserves and acquisitions); 17 on liabilities (pensions, post-retirement benefits other than pensions, environmental liabilities, deferred taxes and stock options); eight on various performance measures (earnings components, various EPS measures, economic value added, cash flow alternatives, comprehensive income and alternative real estate investment trust measures); two on foreign income and exchange gains and losses; 15 incremental and relative association studies on different countries' accounting methods; one on intemporal value relevance; and one on fundamental analysis.
} 
highly associated with the market value of equity. Since the book value of net assets is the book value of equity, this program would be similar to a program aimed at selecting alternative book values of equity based on their relative association with the market value of equity. The incremental association program would end up with a book value of equity that is a transformation of the market value of equity. Now assume the FASB adopts a measurement approach and selects the accounting measure for each asset or liability that measures the market value of that asset or liability with least error. If the program was very successful, each asset and liability measure would approximate its market value and the book value of equity would approximate the market value of equity. Given the valuation model, a standard setting program based on measurement or incremental association would end up providing equity value estimates directly or measures that could be transformed into equity value estimates. The same point could be made for a program of measurement or incremental studies studies on earnings components using a given earnings valuation model: earnings would become an estimate of equity value or the change in equity value, depending on the chosen valuation model, or a measure that could be transformed into an equity value estimate.

Most value-relevance researchers likely do not believe that either the book value of equity or earnings should be an estimate of equity market value or a measure that can be transformed into an estimate of equity market value. Many are careful to indicate that they are only providing information to standard setters that the standard setters can weigh along with other relevant factors (see Barth, 2000, pp. 8-9), that they are merely assessing the relevance and reliability of alternative accounting estimates, or that they are testing the claims of various parties about the properties of alternative accounting estimates. But, the other factors' nature and trade-off with value relevance are not discussed in the literature. Thus, the validity of any standard setting inferences drawn from this literature, or the extent to which this literature can inform standard setters, depends positively on the extent to which accounting is concerned with equity valuation and providing estimates of equity values, and negatively on the extent to which accounting plays other important roles.

The underlying premise in the value-relevance literature is that accounting's primary or dominant role is the valuation of equity securities. To the extent accounting 
has other roles, the value-relevance literature's lack of consideration of those roles assumes an accounting measure's usefulness in other roles is captured by its association with equity valuations. In this paper we refer to this underlying assumption of the literature as the value-relevance criterion.

\section{FASB Statements and Value-Relevance Theories}

In the previous section we argue the value relevance literature's tests imply accounting's role is equity valuation and that accounting fulfils that role by providing estimates of value or transformations of value. In deriving their tests, value relevance researchers often rely on some FASB statements about the nature of accounting and standard setting. Our first point in this section is that other FASB statements explicitly contradict the implication that the FASB intends accounting to provide estimates of equity valuation. Assuming FASB statements are consistent, we compare assumptions made in deriving value relevance tests to FASB statements and ask what assumptions are made that could lead to that contradiction. The first assumption we identify is that the FASB considers users other than equity investors and uses other than valuation of equity securities in determining accounting standards. Indeed, FASB statements do not imply the FASB regards provision of inputs to equity valuation as the sole, or even dominant, function of financial statements let alone that equity valuation is accounting's role. Thus, relevance do not require an accounting measure to be a measure of an equity valuation model input. The second assumption made in the value relevance literature that we identify as not implied by FASB statements is the assumption that stock prices adequately represent equity investors' use of information in valuing equity securities. The third assumption we identify is that the tests of relevance and reliability teased from stock prices do not necessarily reflect reliability as defined by FASB statements.

In reaching the above conclusions, we assume the FASB's stated position predicts their standard setting actions or indicates the actions they take if unconstrained by other factors (e.g., cost). Of course, it is possible that the FASB's actions deviate from their stated position, so in the following section we also examine whether the properties of financial statements are consistent with the implicit standard setting and accounting theories underlying the value-relevance literature. 


\subsection{FASB statements and the value-relevance criterion}

The FASB explicitly denies that financial accounting's objective is to value equity: "information (provided by financial reports) may help those who desire to estimate the value of a business enterprise, but financial accounting is not designed to measure directly the value of an enterprise." (SFAC No. 1, paragraph 41).

The FASB statement's denial of a direct valuation role for accounting suggests there are factors apart from the value-relevance criterion that enter into the determination of accounting and its standards; factors that cannot be captured by that criterion. These factors prevent accounting standard setters from adopting accounting standards that value equity directly. A comparison of the assumptions of the theories underlying the valuerelevance literature with FASB statements, can help us identify factors that impact accounting and its standards but which are misstated in, or missing from, the valuerelevance literature. This serves two roles. First, it helps identify why the valuerelevance literature is likely to have a limited impact on standard setting. Second, it yields some interesting research questions that might provide additional relevant information to standard setters, while at the same time improving our understanding of the theory of accounting.

\subsection{FASB statements and assumptions underlying value-relevance}

Examples of assumptions in the theory underlying the value-relevance literature that are not consistent with FASB statements are discussed below. We focus on assumptions about the users and uses of financial reporting, the reflection of individual decisions in the aggregate market as reflected by the stock price and the definition of reliability.

\subsubsection{Users and uses}

Based on SFAC No.1 and the FASB's mission statement, value-relevance papers assume the objective of financial reporting is to provide information useful in making business and economic decisions. As we noted in the previous section, the valuerelevance literature assumes investors are the users of accounting numbers and their 
prime use is in valuing firms for investment decision purposes (see Lambert, 1996, p. 6; and Barth, 2000, p. 10). Since all of the empirical work in the literature involves equity values, in practice "investors" has come to mean equity investors.

The value-relevance literature's assumptions about the users and uses of financial reporting are not representative of FASB statements about users and uses. The FASB includes among its definition of users individuals who are not primarily interested in equity valuation including some that may not be interested in valuing any of the firms securities. The FASB considers external investors and creditors to be users of information provided by financial reporting (SFAC No.1, paragraphs 30 and 35). The terms "investor" and "creditor" are broadly defined to include actual and potential holders of equity and debt securities, trade creditors, customers and employees with claims, lending institutions, and individual lenders.

The FASB statements about the uses of financial reporting do not suggest any primacy for equity valuation. The FASB describes financial statements as generalpurpose statements that provide inputs to a range of different decisions that have generally similar (but not identical) information demands (see SFAC No. 5, paragraphs 15 and 16). Some of those decisions involve valuation. For example, the FASB's concern with users assessing cash receipts from dividends or interest and proceeds from sale, redemption or maturity of securities or loans (SFAC No.1, paragraph 37) suggests it is concerned with the valuation use of financial reports. Other statements, however, suggest many uses that need not involve equity valuation. For example, SFAC No. 1, paragraph 49 suggests a concern with demands by lenders for assessing whether the firm is in financial difficulty, for assessing liquidity and solvency. Accounting ratios that measure solvency and liquidity are used in monitoring debt contracts (see Holthausen, 1981; Leftwich, 1981; Holthausen and Leftwich, 1983; and Sweeney, 1994). When these ratios reach their specified values they generate an investigation of the borrower's solvency. The FASB also explicitly recognizes management stewardship and corporate governance users of financial reporting (SFAC No. 1 paragraphs 50-53).

The FASB's listing of broad ranges of users and uses and its emphasis that as a consequence financial statements are general purpose statements strongly suggest the assumption that financial reporting and financial statements are primarily aimed at equity 
investors and equity valuation is not descriptive. Moreover, it suggests that those different uses are not served by the same information that an equity investor might choose.

Implications for value-relevance literature. Equity value-relevance is not a necessary condition for standard setting given the FASB's broad definition of users and uses. For example, creditors and lenders are more interested in valuing a firm's debt and default probability than in valuing the firm's shares. Given the value-relevance rationale, this suggests that studies using loan values might provide different results to studies using equity values. It is not apparent that the relevance of a given number would be the same for equity investors and lenders. For example, variables that provide information about the value of a loan, bond, or an accounts receivable if the firm defaults, may not explain cross-sectional variation in equity values for a sample of firms where the liquidation probability is low. The value of future growth options in the event of a firm's success are likely to be more relevant to equity investors than to lenders, bond investors or creditors. If the firm is successful, the individual creditor is paid the face value of the debt and doesn't have any claim on the growth options that result from the success. This is important because it implies that there is no absolute construct of relevance and reliability that can be gleaned from association with equity values. What is relevant for one user or user group, may not be relevant for another. Relevance and reliability as assessed from a lender's perspective may be quite different from that of an equity investor.

We do not observe any value-relevance studies using bond, loan or debt values as the dependent variable, perhaps because those values are less readily available. However, even if a researcher were to conduct a study using bond or loan values, it would still be important to design a study that would have the power to detect the relevance of default information for valuing bonds or loans. In particular, it may be necessary to use a sample of firms where the probability of default is substantial.

\subsubsection{Stock prices and individual investors' use of information}

As Lambert (1996, pp. 6-7) points out, the value-relevance literature uses stock prices to assess investors' use of financial reporting information because those prices 'represent the aggregation of individual investors' valuations of the firm and the 
information upon which that valuation is based." The use of this aggregate measure narrows the scope of equity investors' information demands from that expressed in the FASB's statements. From its statements, the FASB is interested in individual investors, not investors in the aggregate as represented by the stock market. This interest could be due to concerns about unequal access to information and different costs of information acquisition. The FASB (SFAC No.1, paragraph 28) states that the objectives of financial reporting "stem primarily from the informational needs of external users who lack the authority to prescribe the financial information they want from an enterprise and therefore must use the information that management communicates to them."

Since stock market prices incorporate more information than that available to any single investor or his advisor, no investor likely has all the information that is incorporated in prices. Similarly, and perhaps as a result, individual investor valuation models and hence demand for inputs to those models can vary substantially in the crosssection in a way not reflected in the market price. In addition, few individuals may be aware of information at the time it is incorporated into stock prices, so information can be timely for many investors when it is not timely for the market in aggregate. The FASB considers timeliness critical for information to be relevant (SFAC No.2, paragraph 56), and defines it as "having information available to a decision maker before it loses its capacity to influence decisions (emphasis added)." For this reason the FASB could be interested in including information in accounting statements of a period later than the period in which it is reflected in the stock price. This would be particularly true if a reliable measure of the information could not be obtained at the time the market incorporated the information (because of verification difficulties - see below).

Implications for value-relevance literature. The virtually exclusive reliance on stock market data in relative and incremental association studies raises issues regarding whether value-relevance studies can appropriately capture the demands of individual investors.

\subsubsection{Reliability and verifiability}

As we noted in section 2, a significant incremental association (as reflected in a significant coefficient on the accounting number of interest) is interpreted as evidence 
that the accounting number meets the FASB's two prime criteria of relevance and reliability. Reliability is interpreted in terms of measurement error. Barth (2000, p. 16) puts it as follows:

"Value-relevant means the accounting amount is associated with some measure of value, e.g., share prices. If the amount significantly increases the power of the estimating equation to explain equity value, then it must be relevant and measured with at least some reliability. If it is not relevant there would be no relation with equity value. If the amount is fraught with 'too much' measurement error, the researcher also would not detect a significant relation."

However, there is an attribute of the FASB definition of reliability that may not be reflected in the significance of the estimated relation. That attribute is verifiability. As a result significant incremental association does not necessarily imply the number under consideration is reliable.

Verifiability is

"the ability through consensus among measurers to ensure that information represents what it purports to represent or that the chosen method of measurement has been used without error or bias." (SFAC No. 2).

SFAC No. 2 also states:

"the quality of verifiability contributes to the usefulness of accounting information because the purpose of verification is to provide a significant degree of assurance that accounting measures represent what they purport to represent. Verification is more successful in minimizing measurer bias than measurement bias and thus contributes in varying degrees toward assuring that particular measures represent faithfully the economic things or events that they purport to represent ..." (paragraph 81) and

"Measurer bias is a less complex concept than measurement bias. In its simplest form, it arises from intentional misrepresentation. But even honest measurers may get different results from applying the same measurement method, especially if it involves a prediction of the outcome of a future event, such as the realization of an asset. Measurer bias can be detected and eliminated by having the measurement repeated with the same results ..." (paragraph 82)

Verification is concerned with preventing misrepresentation. Misrepresentation in financial statements occurs because the management responsible for preparing the statements has better information than the auditor and the investors and has an incentive 
to misrepresent. There is an information asymmetry and an agency problem. For example, management's incentives to misrepresent may stem from the fact they are evaluated and compensated on accounting performance measures from the published audited financial statements to which FASB standards apply. In addition, management is often evaluated and compensated on the basis of the firm's stock price, which may be temporarily influenced by misstatement. Note management's incentive is not necessarily always to bias performance measures upward, in some cases they have incentives to bias downward (e.g., bonus plans can provide such an incentive, see Healy, 1985). Management also has incentives to bias accounting numbers because of debt contracts that use audited published financial statements (see Watts and Zimmerman, 1986). Note also that in order to mislead auditors and the stock market about their manipulation, management may introduce noise as well as bias.

Assuming efficient markets, measurement method and measurer errors and biases will be reflected in the value-relevance of accounting numbers. For example, an incremental association study's coefficients' magnitudes and signs can be affected. Biases will affect the magnitudes since the coefficients will reflect them. Measurement errors can affect the magnitudes and signs with the effect depending on the correlation structure among the true values of the independent variables and the measurement errors (see Barth, 1991; and Lambert, 1996). If management incentives to bias and introduce measurement error are present, lack of verifiability will affect the reliability and the value-relevance of the accounting numbers.

Implications for value-relevance literature. Identifying potential verifiability difficulties is likely to be a serious problem when value-relevance researchers are evaluating accounting numbers or methods that are not currently included in GAAP and so are not currently reflected in actual financial statements used in compensation contracts, debts contracts, etc. The estimated accounting numbers used in the research have to be estimated (e.g., the environmental liability estimates of Barth and McNichols, 1994) or obtained from existing disclosures in footnotes or other sources (e.g., Barth, 1994), or directly from firms (as in the case of other post-retirement benefits). Such estimates or disclosures, even if produced by management prior to their forced recognition, could be relatively free from bias and noise because the managers' 
incentives to bias and include measurement error are not as strong. In that case, the coefficients and their significance would not be affected by the lack of verifiability. However, once the numbers are included in the financial statements, the incentive to misrepresent increases and if the numbers are not verifiable they could become useless for decision-making and unrelated to stock price. Failure to consider the potential verifiability of the numbers in value-relevance studies could lead to misleading results even ignoring the other problems raised in this section.

An accounting number that is value relevant in a study before it becomes part of GAAP could well cease to be value relevant after it becomes part of GAAP, if it is not verifiable. Standard setters must address issues of this type in their determination of accounting standards. Thus a finding of value-relevance is not a sufficient condition for an accounting standard.

The verification aspect of financial statements may perform an important role in generating more timely credible voluntary disclosures by firms, disclosures that make required disclosures less timely in the sense of conveying information to the market in aggregate. Management's knowledge that the effect of events disclosed will be reflected in the near future in audited financial statements or required disclosures controls management's incentives to issue misleading voluntary disclosures making those disclosures more credible. This reinforces the point made earlier that marginal information content is unlikely to be a necessary condition for standard setting. If the required audited number was not reported because it had no marginal information content, the pre-empting voluntary disclosure may no longer be credible and may lose its marginal information content. An important function of audited financial statements may be in supplying credibility to other disclosures and information.

\subsection{Conclusion}

We have observed that for multiple reasons, value-relevance, as defined in the literature, is neither a necessary nor sufficient condition for standard setting given the FASB statements about how it sets standards. The FASB's statements imply that it is concerned with a multitude of users, uses and financial accounting attributes in the determination of standards. The many other uses and requirements of accounting 
potentially limit the impact of the value-relevance literature on standard setting. However, as social scientists, we should not just accept what the FASB says it does, we should also investigate what the FASB does. The next section investigates whether the value-relevance literature plays a central role in explaining FASB actions as reflected in accounting practice and the extent to which commonly observed attributes of accounting information are inconsistent with the value-relevance criterion. Of course, accounting practice not only depends on the FASB actions, but also on the implementation of GAAP, which in turn depends on preparers, auditors and the SEC.

\section{Value-Relevance and GAAP}

Although the value-relevance criterion is neither necessary nor sufficient for standard setting given the FASB's description of standard setting, it might describe the way the FASB behaves. More broadly, perhaps it describes GAAP and the accounting that we observe in practice. Does the observed association between earnings and stock prices suggest GAAP is created to maximize that association, or that changes in GAAP are attempts to increase that association? Does the nature and evolution of contemporaneous balance sheets suggest GAAP is designed to equate the book value of equity with the market value of the equity? This section asks those questions and concludes that in practice GAAP does not value the equity in the balance sheet or report earnings that attempt to measure value changes or value levels. Nor does GAAP try to estimate transformations of value or value changes. In practice, as in the FASB statements, the income statement and balance sheet are asked to serve multiple functions and non-valuation functions have important implications for the form and content of those statements.

The above conclusion is important because the value-relevance criterion implies that accounting's fundamental role is to measure or help to measure market value and the value-relevance literature ignores other forces affecting the form and content of financial statements. To the extent those other forces are pervasive, the usefulness of the valuerelevance research is diminished. While authors of value-relevance studies may not claim the value-relevance criterion is the only criterion for standards, the accounting 
literature's concentration on that criterion impedes the development of a descriptive theory that is useful to standard setters. Development of a theory that explains all the factors important for the determination of accounting standards and the conditions under which they are more or less powerful, would be a substantive addition to the accounting literature.

To gain insights into why the balance sheet and earnings are not simply measures of value (or transformations of estimates of value) we identify some characteristics of the income statement and balance sheet that are inconsistent with, or are not explained by, the valuation criterion and investigate alternative explanations for those characteristics. In some of those cases the characteristics are consistent with financial statements providing inputs to investors' decision models that involve valuation. For example, the contents of the balance sheet are consistent with the balance sheet being an input to valuation (as described by the FASB), but are inconsistent with it being an estimate of value itself.

In other cases, the identified characteristics are not explained by either the literature's position that the predominant function of financial statements is to provide inputs to valuation or the value-relevance criterion. For example, there is evidence not only that financial statements prepared under US GAAP exhibit significant conservatism (e.g., Basu, 1997; and Ball, Kothari and Robin, 1999), but also that the exhibited conservatism increased under formal standard-setting regimes, particularly that of the FASB (see Basu, 1997; Givoly and Hayn, 2000; and evidence reported later in this paper). Four non-mutually exclusive hypotheses that could explain conservatism and its increase are considered: litigation, contracting, political and tax considerations. All four hypotheses are consistent with some casual and/or formal evidence. The section concludes by investigating the mechanisms by which litigation, contracting and tax could influence standard setting.

\subsection{The nature and evolution of the balance sheet}

The nature of the balance sheet and its evolution over time are inconsistent with the balance sheet's role being to value the firm or equity. The nature and evolution of the balance sheet are consistent with the provision of inputs to valuation being one of the 
balance sheet's multiple functions. That evidence is consistent with contracting being another of those multiple roles. Finally, the evidence suggests litigation and political considerations influence the form and content of the balance sheet.

\subsubsection{The nature of the balance sheet}

The balance sheet today still consists mostly of individual, separable assets and liabilities just as it did prior to the Securities Acts. The FASB's reintroduction of market value accounting is for individual assets, not for the firm. ${ }^{6}$ There is no attempt to value the firm or equity directly in the statement of financial position. The valuation of individual assets is consistent with the balance sheet providing an estimate of the market value of net assets. However, the market value of net assets is only one ingredient to valuation, and generally, equity valuation would additionally require valuation of the firm's future cash flows (see next section). The general nature of the balance sheet is more consistent with several alternative hypotheses about its function than with direct equity or firm valuation. For example, the balance sheet's nature seems more consistent with it providing an input to firm and loan valuation, in particular the value of the abandonment option, as opposed to valuation of the firm or equity directly.

The view that the book values of assets are estimates of their separable market values is also consistent with another non-mutually exclusive hypothesis about the role of accounting - the contracting role of audited financial statements. For example, debt contracts use book values of assets and liabilities as estimates of the resources and debt claims of the firm to trigger covenants that restrict management actions that reduce firm and debt value (see Smith and Warner, 1979; and Leftwich, 1983).

The treatment of goodwill in practice provides insights into whether the balance sheet is intended to measure the value of the firm. Goodwill represents the difference between the market value of the firm and net assets (as well as omitted assets). It is recorded only if purchase accounting is used, and if recorded, is amortized. This treatment is inconsistent with standard setters pursuing a value-relevance criterion in an

\footnotetext{
${ }^{6}$ Individual assets were occasionally revalued to market prior to the SEC, often prior to new financing (see Finney, 1935, chapter 40). Also, revaluations of individual assets continue to occur today in other AngloAmerican accounting countries.
} 
unconstrained manner, since goodwill is not revised periodically to make equity equal to firm value.

The recording of goodwill at all seems inconsistent with debt-contracting since debt agreements use the reported financial statements but generally exclude goodwill and intangibles (see Leftwich, 1983). This inconsistency could be due to other factors. ${ }^{7}$ Prior to the SEC, goodwill was often written down to a nominal amount (see Ely and Waymire, 1999a, p. 15) with a write-off against equity (a practice that was common in the UK until recently). This practice is consistent with debt contracting. Debt-contracts likely excluded goodwill from the balance sheets because in liquidation, goodwill would presumably be zero (continuing the firm would not be a positive net present value project).

Another contracting role of the balance sheet relates to executive compensation contracts. Some executive compensation contracts use the book value of assets or equity to assess whether the firm earns a return above a normal rate of return on the firm's assets or net assets (see Smith and Watts, 1982; Healy, 1985; and Holthausen, Larcker and Sloan, 1995). Such use is appropriate if the book value of assets is an estimate of the market value of the separable assets or the book value of the equity is an estimate of market value of the separable assets, net of liabilities. This view of the balance sheet is supported by the FASB's description of the complementarities of the balance sheet and the statements of earnings and comprehensive income:

"Statements of earnings and comprehensive income generally reflect a great deal about the profitability of an entity during a period, but that information can be interpreted most meaningfully or compared with that of the entity for other periods or that of other entities only if it is used in conjunction with a statement of financial position, for example, by computing rates of return on assets or equity." (SFAC No. 5, paragraph

\footnotetext{
${ }^{7}$ An interesting issue is why didn't firms immediately write-off goodwill. The answer likely has to do with the effects of such a write-off on the firm. Many large US industrial firms formed by mergers of existing firms around 1900 had the par value of their shares considerably higher than the tangible book value of the merged firms. The alternative for these firms was to record the difference between par and tangible values as a discount on issue, a number that would have to be eliminated via profits before dividends could be paid (see Ely and Waymire, 1999a, p. 13). Writing off goodwill would have imposed the same dividend constraint on the firm. By the late 1920's it appears that most of these firms had been able to write off these intangible assets. It would be interesting to investigate the firms that had capitalized goodwill in the 1920s to determine if the failure to write-off goodwill was associated with similar constraints on dividends or financial policy (by then states had revised their laws that required large par values). The explanation for the capitalization of purchased goodwill today could well lie in related constraints on firms.
} 
24a)

\subsubsection{The evolution of the balance sheet}

The evolution of the balance sheet in the US is not only consistent with the balance sheet providing an input to valuation and to contracting, it suggests political and litigation considerations play a role in shaping the form and content of the balance sheet. Prior to the creation of the SEC and formal standard setting, the input to loan valuation and debt contracting played dominant roles in shaping the balance sheet. According to SFAC No. 2, paragraph 93, prior to the SEC the balance sheet was the primary financial statement and bankers and other lenders were the primary users.

Prior to the SEC, asset values were written up (as well as down) to market or "current values" consistent with both loan valuation input and debt contracting. Most of the upward revaluations were of property, plant and equipment or investments (assets that could be used as collateral). Fabricant (1936) found that in a sample of 208 large listed industrial firms, there were 70 write-ups of property, plant and equipment and 43 writeups of investments in the period 1925-1934. There were only seven write-ups of intangibles for the sample, consistent with the accountants' recommendations at the time that rights-based intangibles be written-up only in exceptional circumstances (see Yang, 1927, p. 166; and Ely and Waymire, 1999a, p. 14) and with debt covenants' tendency to exclude intangibles.

Revaluation was often associated with new financing (see Finney, 1935, chapter 40). Presumably, revaluation occurred when the marginal benefit exceeded the cost. If a property had already been revalued by an independent appraiser for debt financing purposes, the marginal cost of reporting it in the financial statements (prior the SEC) would seem relatively low. The marking of individual assets to market at the time of new financing is consistent with the balance sheet being an estimate of net asset value for the purposes of lending and valuing the loan. It is also consistent with the debt-contract use of financial statements since the revalued numbers serve as the base for the book values used to control management actions and monitor the borrower during the life of the debt contract. Note that write-ups after the loan do not typically increase the net assets for the purpose of the loan contract (see Leftwich, 1983, p. 32).

The political process appears to have entered standard setting sometime in the late 
1930s. By 1940 the practice of revaluing fixed assets was "virtually extinct" (Walker, 1992, p. 3). The SEC used the registration process to eliminate these write-ups. The elimination of fixed asset revaluation appears tied to the emergence of political considerations in accounting standard setting. In particular, several founding commissioners of the SEC were associated with a public political argument that the financial difficulties of the 1930s were due to asset write-ups. ${ }^{8}$ Empirical research suggests the argument was false. ${ }^{9}$ Given their prior public argument, the commissioners could not allow asset write-ups to continue. Once in place for a number of years, the policy was difficult to change. Many recent examples also point to the effects of the political process on the setting of accounting standards in general (e.g., the recent debates on accounting for stock options, Beresford, 1996, fair value accounting, Johnson and Swieringa, 1996, and the recent purchase/pooling debates).

From 1940 until the 1970s the SEC effectively banned upward asset revaluation in the financial statements and even disclosures of current values. When the SEC lifted its ban in the early 1970s, few firms voluntarily wrote-up their assets. In the 1970s, as in the 1920s, investors making equity and debt investment decisions undoubtedly still demanded information about the market values of the separable assets. So the failure of the return to marking fixed assets to market in the 1970s is inconsistent with both the FASB's valuation input demand and contracting. What changed in the interim? A reasonable hypothesis that has supporting evidence, is the failure to mark fixed assets to market was due to the growth in class action lawsuits against listed firms. This growth occurred after the 1966 revision of Rule 23 of the Federal Rules of Civil Procedure and the consequent increased legal liability for overstatements of assets and earnings (see Kothari, Lys, Smith and Watts, 1988; and Basu, 1997).

\footnotetext{
${ }^{8}$ Some of the SEC's initial staff were drawn from the Federal Trade Commission (FTC) and three of the SEC's founding commissioners were involved in the FTC's dealings with public utilities" (Walker, 1992, p. 7). The most outspoken opponent of write-ups was "Judge" Healy, a foundation SEC commissioner who headed the FTC's investigation of the financial affairs of utilities, an inquiry that became protracted following the utilities' financial difficulties in the early 1930s. That experience apparently soured Healy on asset write-ups. The FTC and Healy considered asset write-ups as an important factor in the utilities' financial difficulties.

${ }^{9}$ Many accountants writing after the stock market crash stated or implied (without formal evidence) that assets written up in the 1920s were written down again in the 1930s. Fabricant's evidence, however, suggests the write-downs involved capitalized intangibles rather than previously revalued fixed assets or
} 
On net, the nature and evolution of contemporaneous balance sheets is more consistent with the provision of an estimate of net asset value as an input into firm valuation and/or contracting than with valuation of the firm per se. There is some suggestion that other factors, in particular the political process and litigation, have also played a role in determining the balance sheet's nature. Overall it seems clear the valuerelevance criterion has not been the prime determinant of the nature of today's balance sheet.

It is important to understand all of the influences that shape accounting in order to derive standard setting implications. For example, measurement techniques are being developed to value assets like customer loyalty. Assuming these techniques were refined, would we want to include these valuation estimates on the balance sheet if their inclusion moved the book value of equity value closer to the market value of equity? Should the customer acquisition costs in the wireless industry be capitalized if that recognition helped equate book and market values of equity? From a debt contracting perspective, the answer is likely no, since the net assets measure the value of the firm under liquidation and if the firm were liquidated, the customer assets might be worth far less than in a going concern. Consider the same perspective in the context of Barth's (1994) investigation of the fair value of banks' investment securities. From a depositor's perspective, one might argue for recognizing the fair value of investment securities in the balance sheet, as it provides estimates of the value of the investment securities, even if the bank is not a going concern. Unlike customer loyalty or goodwill, where the assets are not likely to be worth very much if the company is not a going concern, the value of the investment securities is likely to represent a reasonable liquidation value. From this perspective, Barth's (1994) setting is likely a reasonable one. ${ }^{10}$

\subsection{The conservatism of the income statement}

An aspect of accounting exhibited by firms all around the world is the

investments (see Walker, 1992, pp. 5-6). There was no evidence that the write-ups overstated the value of separable tangible assets for industrial listed firms.

${ }^{10}$ However, political considerations may be operating in this environment and that can affect the accounting methods used in the balance sheet. For example, savings and loans regulators allowed S \& L's to continue to value assets above market to delay closure of insolvent S\&L's and to encourage their acquisitions (see Andrew, 1981; and Barth, Bartholomew and Bradley, 1990). 
conservatism of the earnings number (see Ball, Kothari and Robin, 1999). This conservatism takes the form of accounting anticipating losses but not gains so that stock prices reflect good news (gains) earlier than do earnings while bad news is reflected in stock prices and earnings more contemporaneously. Stock prices lead earnings more for gains than for losses. Delaying recognition of gains while anticipating losses leads to the understatement of net assets. Conservatism could be due to contracting, litigation and/or tax issues, thus highlighting the multi-purpose aspect of financial statements. The pattern of conservatism observed around the world, and in the United States over time, is not explained by the value-relevance criterion.

The degree of conservatism observed in US income statements is inconsistent with the FASB's stated views. In SFAC No. 2, paragraph 93, the FASB states that conservatism "was once commonly expressed as the admonition to 'anticipate no profits but anticipate all losses" and "Conservatism in financial reporting should no longer connote deliberate, consistent understatement of net assets and profits." SFAC No. 2 attributes the development of conservatism to "bankers and other lenders who were the principal users of financial statements (prior to the SEC)." The Statement further remarks (in 1980) that the "notion became deeply ingrained and is still in evidence despite efforts over the past 40 years to change it."

\subsubsection{Conservatism arising for contracting purposes}

Watts (1993, pp. 3-7) hypothesizes as to why conservatism might have evolved for both management and debt contracting purposes. Conservatism reinforces debt contract provisions that ensure resources are kept within the firm to meet obligations to lenders. Conservatism defers the recognition of income and, when combined with restrictions on dividends, reduces the likelihood that resources will be distributed inappropriately to parties with claims of lower precedence than the lenders. It performs much the same function as the liquidator's recognition of all potential losses before making an interim distribution of funds to claimants on the firm.

Hayn (1995) and Basu (1997) find that the relation between annual earnings and annual stock returns for US firms varies according to the nature of the news for the year. Hayn finds that the slope coefficient and the $\mathrm{R}^{2}$ in a regression of stock returns on 
earnings are higher for firms showing profits than for firms showing losses. Basu conducts a "reverse" regression of annual earnings on annual returns and finds that the slope coefficient and the $\mathrm{R}^{2}$ are higher for firms with negative unexpected returns than for firms with positive unexpected returns for the year. As Basu shows, the two sets of results are essentially the same phenomena. "Bad news" tends to be more fully reflected in both current earnings and returns than "good news." Losses are anticipated and written off at the time of the news. Good news affects the current year's return but the profit is not fully anticipated and is spread over the earnings of current and future years. In a given year the earnings effect is smaller relative to the return effect for profits than for losses. The consequence is that the slope coefficient is higher for profits than losses if returns are regressed on earnings, but lower if earnings are regressed on returns.

The effect documented by Hayn and Basu is consistent with conservatism: "anticipate no profits but anticipate all losses." While Basu hypothesizes the effect is due to conservatism, Hayn hypothesizes it arises because of the abandonment option. Shareholders prefer to abandon the firm rather than bear predictable losses, hence observed losses are likely to be temporary. Basu discriminates between the two hypotheses on the basis of the effect of accruals on the extent to which earnings are contemporaneous with returns and on the time series variation in the earnings-return relation. He concludes the evidence is more consistent with conservatism.

The extent to which bad news is contemporaneous in earnings and returns is substantial in Basu's study. Earnings are four and a half times more sensitive to negative returns than to positive returns over the period, 1963-1990. Ball, Kothari and Robin (1999) perform similar regressions on US and non-US firms for the period 1985-1995 and find earnings is ten times more sensitive to negative returns than to positive returns in the period 1985-1995. UK earnings are five times more sensitive to negative returns than to positive returns over the same period. These results suggest a high degree of conservatism in US accounting, twice that observed in UK accounting, despite SFAC No. 2's condemnation of conservatism.

Ball, Kothari and Robin (1999) find evidence of conservatism in 19 of 25 countries they study. Moreover, they hypothesize the demand for conservatism is less in code law than common law countries because of lesser information asymmetry problems 
in code law countries arising from the different governance structures. They find evidence consistent with their predictions and so consistent with a contracting explanation. Further, the value-relevance criterion for assessing accounting standards offers no explanation for the pervasive existence of conservatism or the varying demand for conservatism around the world. While one of accounting's roles is providing inputs to valuation, the substantial asymmetry between good news and bad news in the association between earnings and stock prices suggests the existence of other strong forces at work, including contracting.

\subsubsection{Conservatism arising from litigation}

As we saw above, conservatism is consistent with contracting. It is also consistent with a litigation motivation. Overstatement of earnings or assets is far more likely to generate a lawsuit than understatement (see Kellogg, 1984, p. 186, footnote 3) and this creates incentives for managers to be conservative in reporting both earnings and assets. Basu investigates the sensitivity of earnings to positive and negative returns over sub-periods of low or high auditor liability identified by Kothari, Lys, Smith and Watts (1988). He finds no differences in the sensitivity to positive and negative returns in the low liability periods, but significant differences in the sensitivity in the predicted direction in the high liability periods. One of the low periods is the period 1963-1966, prior to the changes in the rules for class actions suits. These results are consistent with the change in litigation climate affecting the degree of conservatism of US accounting. ${ }^{11}$

\subsubsection{Conservatism and corporate income taxes}

The existence of corporate income taxes can also lead to conservatism in accounting. Guenther, Maydew and Nutter, 1997, pp. 230-234) discuss the effect of court decisions and IRS behavior on the relation between accruals for tax purposes and accruals for financial reporting purposes. They conclude (p. 232): "Overall, the evidence suggests the existence of implicit pressure to conform tax accounting methods to those

\footnotetext{
${ }^{11}$ However, alternative explanations and countervailing evidence exist. Ball (1989) argues that the change in litigation climate could have been driven by contracting changes. Further, Ball, Kothari and Robin (1999) point out that in recent years the asymmetry of sensitivity of earnings according to good or bad news has also increased in France and Germany where litigation is not particularly an issue.
} 
used for financial reporting purposes." Guenther, Maydew and Nutter present empirical evidence that firms forced to switch for tax purposes from the cash method of accounting to the accrual method by the Tax Reform Act of 1986, increased their deferral of income for financial statement purposes (became more conservative).

Whether or not it is contracting, litigation, political pressure (as in the lack of revaluation of fixed assets), income taxes, and/or something else that is causing the conservatism of US accounting practice, conservatism is not explained by the valuerelevance criterion. Moreover, conservatism appears to be part of accounting practice around the world, albeit, in varying degrees.

\subsubsection{Evidence on conservatism over time in US financial statements}

In this section, we provide evidence on the conservatism in US financial statements over time. We find that conservatism in US financial statements (i) existed prior to formal standard setting in the US, (ii) has increased over time, and (iii) has increased to the point where virtually all of the association between earnings and stock prices is driven by bad news.

Despite the FASB's condemnation of the notion of conservatism that implies different standards for recognizing gains versus losses (SFAC No. 2), there is evidence that conservatism in earnings of US listed companies has increased significantly during the FASB's tenure (see Basu, 1997; and Givoly and Hayn, 2000). Basu (1997) finds no evidence of conservatism prior to 1967 (see Basu, 1997, table 6) and that most of the increase in conservatism occurs after the establishment of the FASB in 1973 (see Basu, 1997, figure 3). This does not imply that the FASB caused an increase in conservatism, as it is possible that the implementation of standards by preparers and auditors, and not the standards themselves, have affected the degree of conservatism.

Basu's failure to find significant conservatism prior to 1970 is puzzling given the many claims that it existed prior to that date. Moreover, such a finding would be inconsistent with the view that conservatism would arise for contracting reasons which implies it should exist prior to the SEC's establishment. We thought the result could be due to Basu's limited number of observations in the period prior to 1970. To investigate that possibility, we asked Kirsten Ely to estimate a regression, similar to that estimated by 
Basu in his table 6, for every year for the 1927-1993 sample of US firms used in Ely and Waymire (1999b). That sample was generated by randomly drawing 100 firms each year from the CRSP Monthly Price File that met two criteria. The criteria were that the firm had (1) stock price data available for 29 months from February of the prior year through June of the subsequent year; and (2) a four digit SIC code between 1000 and 3999. Earnings data were obtained from Compustat or Moody's Industrial Manual and were not available for 30 of the 6,700 firm/years in the sample. Most of these 30 firm/years are in the pre-1951 (pre-Compustat) period. All years have at least 97 observations available.

The exact form of the regression estimated is:

$$
X_{t} / P_{t-1}=\alpha_{0}+\alpha_{1} D_{t}+\beta_{0} R_{t}+\beta_{1} D_{t} R_{t}
$$

where $X_{t}$ is the firm earnings or operating earnings per share for year $t, P_{t-1}$ is the price at the beginning of year $t, \mathrm{DR}_{t}$ is a dummy variable equal to 1 if $\mathrm{R}_{\mathrm{t}}<0$ and zero otherwise, and $R_{t}$ is the rate of return on the firm's stock for year $t$. The test for conservatism is whether the slope coefficient for the last term is significantly positive.

Mean estimated coefficients and mean t-statistics are calculated for sub-periods reflecting different standard setting, regulatory and litigation regimes. Those sub-periods are $1927-41,1942-46,1947-50,1951-53,1954-66,1967-75,1976-82$ and 1983-93. The last three sub-periods are used by Basu and represent regimes of standard setting with high, low and high litigation, respectively. The periods 1942-46 and 1951-53 are periods of general price controls that appear to affect the earnings/stock return relation. The period 1927-1941 includes the period prior to the SEC's elimination of write-ups in 1940 (1941 is included rather than merely eliminating it — its exclusion does not affect the results). We consider the 1927-41 to be a period without standard setting or litigation. The periods after 1941 all had standard setting. Those prior to 1967 had virtually no litigation. Litigation increased significantly in 1967-75, decreased in 1976-82 and increased significantly again in 1983-93. Mean coefficients are calculated for the 196366 period for comparison to Basu's results.

Table 2 reports mean coefficients for the overall sample period and for each subperiod for both earnings and operating earnings. The table also reports Basu's results and the results of Ball, Kothari and Robin (1999) for a similar regression. Basu uses a sample of 43,321 firm years in the period 1963-1990. He estimates a pooled regression with 
dummies on the coefficients for particular sub-periods. We report sums of estimated coefficients from the Basu regressions that are comparable to the estimated coefficients from the Ely regressions. Earnings and returns in the Basu regressions are adjusted for market earnings and returns. Ball, Kothari and Robin (1999) run pooled regressions for two sub-periods of the 1985-95 period, using earnings before extraordinary items rather than earnings. The Ball, Kothari and Robin 1985-90 regression is over 11,978 firm/years and their 1991-95 regression is over 9,247 firm/years.

From table 2 we see that for earnings, the mean coefficient of the dummy variable multiplied by return is significantly positive in the period prior to standard setting and litigation (1927-1941) and all periods post 1953 (other than the 1963-66 period). The significance of the pre-standard setting period (1927-41) is consistent with our expectations that conservatism existed prior to formal standard setting and concerns about litigation. The insignificance of the coefficient for that period in the operating earnings regressions suggests non-operating items are largely responsible for the conservatism. Our insignificant result for the 1963-66 period confirms Basu's result but suggests that period is not representative of the pre-litigation and standard-setting period. The lack of significant conservatism and the large significant mean coefficient of the return variable in the World War II price control period suggests those controls changed reported profits substantially.

Like Basu's results, our results in table 2 indicate a substantial increase in conservatism since the creation of the FASB: for regressions using earnings, the coefficient of the dummy multiplied by the return increases from something less than .10 before 1976 to .16 in the period 1976-1982 and .43 in the period 1983-1993. Similar increases are observed for the regressions using operating earnings, especially in the 1983-1993 period. Unlike Basu's results, table 2 shows the increase beginning in the earnings regressions in the 1976-82 period rather than the 1967-75 period. This difference could be due to different specifications of the regressions as well as differences in the sample. The result remains though, that conservatism has increased during the FASB regime, though we do not attribute causality to the FASB.

Note also that in the earnings regressions the value-relevance of earnings in good news years (the mean coefficient of return) decreases during the FASB regime and 
becomes zero and insignificant in the last (1983-93) period. In the operating earnings regressions, though, the value-relevance of good news is still significant in the last period. Basu also reports a coefficient close to zero (but still significant) in the last period and Ball, Kothari and Robin (1999) report a significant coefficient, which is close to zero in the period 1985-95. These results suggest valuation (whether in the form of the valuation criterion or the form of provision of inputs to valuation) is not the sole force, and perhaps not even the dominant force, at work in the contemporaneous accounting model. ${ }^{12}$

\subsection{The existence of dirty surplus}

US accounting standard-setters have periodically professed a desire to require clean surplus (e.g., APB Opinion No. 9 in 1966, SFAC No.5 in 1984 and FASB Statement No. 130 in 1997). Clean surplus means that changes in the book value of equity, other than those resulting from transactions with equity holders (investments and dividends), flow through earnings. An objective of a clean surplus policy is "to avoid discretionary omissions of losses (or gains) from an income statement, thereby avoiding presentation of a more (or less) favorable report of performance or stewardship than is justified" (SFAC No. 5, paragraph 35). Dirty surplus is surplus that is dirtied by the inclusion of the effects of non-equity holder transactions that have not flowed through earnings. US standard setters' professed desire to follow a clean surplus policy has not been fulfilled. Their difficulty in achieving clean surplus and the existence of dirty surplus in other Anglo-American countries is not explained by the value relevance criterion and suggests multiple forces are at work in determining accounting standards.

After the issuance of APB Opinion No. 9 in 1966, standard-setting bodies in the US nominally followed a clean-surplus policy. More recently, the FASB included a clean surplus policy in SFAC No. 5 (paragraph 13) in 1984. In practice, however, the clean surplus policy has not been followed very strictly. For example, the FASB allowed certain gains and losses to by-pass the income statement and go directly to equity

\footnotetext{
${ }^{12} \mathrm{An}$ issue we do not discuss, but also worth investigating is the conservative properties of the balance sheet. We know that assets are much more likely to be written down than written up (lower of cost or market rule, rules on write-downs of assets, etc.). Moreover, we know that average price/book ratios are
} 
(unrealized gains and losses on marketable securities, the change in foreign currency translation adjustment and additional pension liability in excess of unrecognized prior service cost). FASB Statement No. 130 requires the disclosure of comprehensive income which, if it were the bottom line of the income statement, would result in clean surplus. However, the statement does not specify the financial statement in which comprehensive income must appear and preliminary evidence indicates that it is disclosed in practice in the statement of changes in equity (see Hirst and Hopkins, 1998, p.49). Thus, in practice, surplus is still dirty.

The magnitude of dirty surplus appears to be material in many cases. Lo and Lys (1999) estimate the amount of dirty surplus as the absolute difference between comprehensive (clean surplus) income and GAAP net income as a percentage of comprehensive net income in the period 1962-1997. They find that while the median deviation is only $0.40 \%$, the mean is $15.71 \%$, and $14.4 \%$ of firm/years have dirty surplus that exceeds $10 \%$ of comprehensive income.

We have argued that consistent application of the value relevance criterion would result in the book value of equity being an estimate (or transformation of an estimate) of the market value of equity and earnings being an estimate (or transformation of an estimate) of the level of or change in equity market value. In doing so, we relied on two of the three valuation models used in the literature (the earnings model and the balance sheet model). The other valuation model used in the literature (the Ohlson model) expresses equity market value as a linear function of current earnings, dividends and book value of equity. In that case the linear combination would be an estimate (or transformation of an estimate) of market value. In none of the three cases can the value relevance criterion explain dirty surplus.

Studies using both earnings and balance sheet valuation models do not explain how the two estimates of value would interact (i.e., how the income statement and balance sheet would articulate). If earnings are an estimate of equity value (or an estimate of the change in equity value) and book equity is an estimate of equity value, how would differentces in the estimates be reconciled in the financial statements? No

well over one in most time periods. This suggest the balance sheet contains many conservative elements as well, another fact that cannot be explained by the value relevance criterion. 
one seems to have thought of that problem. ${ }^{13}$ The third valuation model, the Ohlson model, uses both the book value of equity and earnings and assumes clean surplus.

The failure of the relevance literature to explain dirty surplus is significant given dirty surplus has existed for most of the period in which we have had formal accounting standards in the US and other Anglo-American accounting countries. Dirty surplus existed prior to standard setting and continues to exist today. Prior to the SEC in the US, unrealized gains from asset write-ups went to surplus rather than income (Dillon, 1979) or were used to offset intangible assets or accumulated losses in retained earnings (Saito, 1983, pp. 14-19). Today upward revaluations of assets in Australia and the UK still go to reserves in owners' equity rather than to the income statement (Brown, Izan and Loh, 1992, p. 37). These observations are inconsistent with clean surplus being an equilibrium accounting choice.

The existence of dirty surplus can be explained by the existence of multiple roles for financial reporting. For example, as we have already noted, the balance sheet could provide an estimate of the liquidation value of net assets for lenders while earnings could be used as a performance measure for compensation contracting and monitoring purposes. Given the different purposes of the statements, dirty surplus would be necessary to have the two statements articulate. The lending role for the balance sheet suggests it would reflect the market value of assets such as property plant and equipment and we noted earlier in this section that prior to the SEC asset revaluation was often associated with financing events. Changes in the values of those assets, however, may be considered beyond the manager's control and so excluded from the performance measure (earnings) that is used for compensation and monitoring purposes. As we saw above, prior to the SEC that is exactly what occurred.

\subsection{How contracting, litigation and taxes affect accounting standards and practice}

Anglo-American accounting had evolved to a significant degree prior to the formation of the SEC and listed firms were audited. There was concern with issues such

\footnotetext{
${ }^{13}$ In some cases (e.g.,Barth, 1994) the lack of explanation is might be due to an implicit assumption that the value relevance criterion will not be used widely in standard setting.
} 
as verifiability and evidence of accounting principles. For example, Dillon (1979) found that, while approximately a quarter of his sample of 110 NYSE firms had an upward revaluation during 1925-34, not one used a revaluation to increase earnings. That observation is consistent with accounting and financial reporting fulfilling a contracting role (see above). Also consistent with contracting was the general view that accounting and financial reporting served a stewardship function (see Zeff, 1999, p. 17). As we have seen, the FASB itself viewed the balance sheet as the prime statement prior to the SEC and considered it a document aimed at lenders. In addition to the parties to the firm itself (e.g., shareholders and managers), a broad set of external institutions (banks, private debt holders, etc.) relied on audited financial accounting reports for contracting purposes.

It is difficult to believe that Congress, the SEC and standard setters could or would be able to take an institution (financial reporting) fulfilling an important economic function (contracting) and, by fiat, totally convert it to a different function. There was a large set of parties with vested interests in the contracting use of the audited financial reports with the resources to oppose changes that made contracting more costly. These interests' potential lobbying with Congress and the SEC likely deterred standard-setters from changing financial reporting such that it did not meet contracting demands. There is some suggestion they did not. As late as 1975 the FASB found that only 37 percent of respondents to their survey agreed that "The basic objective of financial statements is to provide information useful for making economic decisions. ... Those who disagreed took the position that the basic function of financial statements was to report on management's stewardship of corporate assets and that the informational needs of readers was of secondary importance" (Armstrong, 1977, p.77). While the increase in litigation could have changed attitudes and actions since 1975, it seems likely that current-day accounting numbers reflect contracting objectives as well as the broad investor information objective.

Litigation and taxes could also affect standard setting via the political process. Auditors and others negatively affected by increased liability under litigation are likely to lobby with Congress and the SEC to make financial statements conservative. Managers and investors in firms affected by a proposal to require the capitalization of development expenditures in the wireless communication industry are likely to lobby against such a 
proposal because of its effect on taxes and firm value.

It is conceivable that we are in a period in which standard setters are moving away from the demands that accounting originally evolved to meet to one that adopts a pure information to equity investors perspective. If this is true, standards should be reflecting the value-relevance criterion or the input to valuation role with increasing frequency. However, the evidence on conservatism suggests this is not the case. Moreover, very recent decisions of the FASB, such as the recent stock options standard, are consistent with a standard setting process that does not follow the value-relevance criterion. Beresford (1996) discusses how the FASB responded to the political pressure arising from its stock options project in order to survive, at the expense of what the board felt was the superior standard. Further, Zeff (1999) details how the FASB's potential reliance on the conceptual framework has been repeatedly broken by political pressure from preparers, users, auditors and Congress. Leftwich (1995) argues that the FASB even sets its agenda by choosing areas where it can restrict the set of currently available choices and appease the SEC. Thus, if we are moving closer to a value-relevance criterion, the move seems almost imperceptible. Moreover, recent evidence (Chang, 1999; and Brown, Lo and Lys, 1999) suggests the value-relevance of financial statements has declined in recent in recent years.

Auditors and managers may also choose to make accruals more income deferring and net asset reducing within the bounds of GAAP causing accounting practice to be more conservative. As we have seen, the evidence of Basu (1997) is consistent with US accounting practice becoming more conservative after increases in auditor liability. There is also evidence that the link between tax and reporting accruals has also become stronger in recent years (see Guenther, Maydew and Nutter, 1997). Institutional arrangements play an important role in the way standards are implemented. Ball, Robin and $\mathrm{Wu}(2000)$ investigate the timeliness and conservatism of virtually identical accounting standards adopted in Hong Kong, Malaysia, Singapore and Thailand. They find large differences in the timeliness and conservatism of earnings as judged by the association between earnings and returns in these four countries. They conclude that the differences are driven by managers' and preparers' incentives to disclose material information, which are a function of the market-orientation of the economy, litigation, 
taxes and political costs. Thus, accounting standards alone, do not determine the properties of the accounting reports, and the same forces that affect the adoption of new standards affect the implementation of those standards as well.

\subsection{Conclusion on value-relevance and GAAP}

It is apparent that the value-relevance criterion does not determine the nature of GAAP, nor is it obvious it is a dominant force. Other factors that appear to affect the nature of GAAP include contracting, litigation, political and tax considerations. None of this means that accounting's role in providing inputs into valuation is irrelevant. What it does mean is that role is only part of the equation.

If, as researchers, we provide standard-setters with value-relevance evidence only, we do the standard-setters a disservice because we ignore the fact that financial statements have multiple purposes. The existence of the competing hypotheses to explain conservatism is due in part to the many roles that accounting statements are asked to fulfill. If we imply that standard-setters should try to make the balance sheet measure firm value when such an outcome is not the equilibrium demand of financial statements users, we encourage standard-setters to fail. In addition, if input to valuation is only a part of the role of accounting, our research will have a small influence on the standardsetting process if we do not take account of the other roles that accounting standard setters consider.

Value-relevance research might be more useful if we could explain when the valuation input role is likely to be operating without interference from other forces and when it is likely to be affected by other factors. Research of that type would require an explicit understanding of the other factors and forces that shape accounting standards and some predictive ability of their strength in varying circumstances. As it is now, the value-relevance literature is attempting to provide evidence that is useful for standard setting without a descriptive theory of accounting or standard setting. Understanding the nature and strength of the other forces that shape accounting would lead to an improved understanding of accounting and should aid standard setters in balancing the multiple objectives of financial reporting.

In the next two sections we ignore the inconsistencies between the rationale for 
value-relevance and what the FASB says and does in setting standards. Instead we assume the value-relevance criterion is correct and look at the implications of the valuerelevance literature's valuation models for accounting standards (section 5).

\section{The Valuation Model and Links to Accounting Numbers}

As we noted, investigating the relation between accounting numbers and firm value requires a valuation model to specify the attributes affecting firm value and their relation to firm value. A link between the accounting numbers and firm attributes is also required. It is important that the valuation model chosen to investigate the relation between accounting numbers and firm value be appropriate for valuing the attributes of the firms investigated in the study. Further, the links between the attributes valued and accounting numbers should be carefully specified to generate implications for those numbers (e.g., as in the balance sheet model in Barth, 1994). In this section we investigate the appropriateness of the valuation models used in the literature and the specification of their links to accounting numbers allow inferences. The ability to make standard setting inferences depends critically on both the valuation model's appropriateness and the links' specification. This is true also of inferences in areas of capital markets research (e.g., valuation literature) so that much of the discussion in this section applies to those areas as well.

The valuation models are often inappropriate for the use to which they are put and the accounting links to those models are often not specified. One result is potentially incorrect predictions for the signs and magnitudes of coefficients of accounting numbers in regressions in incremental association studies. Another is an exacerbated correlated omitted variables problem.

In many incremental association studies of balance sheet components, the valuation model is that the market value of equity is equal to the market value of the assets minus the market value of the liabilities (e.g., Barth, 1991). We label that the balance sheet model. Twenty-one studies in Table 1 use the balance sheet model and 20 of them are incremental association studies. The model holds only if all the relevant markets exist (there is a market for each asset and liability as well as for the stock) and all markets are competitive so there are no expected above-competitive returns (rents) to the 
firm. In addition, there can be no corporate control frictions, so management liquidates the firm if that is the optimal action. In other words, we would not observe a firm's market value below the market value of its net assets. The link between the accounting numbers and the attributes valued is that book values of accounting assets and liabilities convey information about the market values of those assets and liabilities.

In earnings association studies, earnings are assumed to be informationally linked to future cash flows or valued directly (earnings model). Consequently, stock market rates of return (or the equity values) are regressed on: i) components of earnings and/or earnings component changes; or ii) earnings and/or earnings changes (e.g., Dhaliwal, Subramanyam and Trezevant, 1999). In some cases, a reverse regression is estimated with earnings regressed on market rates of return (as in Beaver, Lambert and Morse, 1980). Twenty-two studies in Table 1 use an earnings model. Eight conduct relative association studies and 18 conduct incremental association studies (four studies conduct both kinds of association studies).

A third specification comes from the Ohlson (1995) and Feltham and Ohlson (1995) which indicates that, given a dividend valuation model and clean surplus accounting, stock price can be written as a linear function of earnings and book value of equity (Ohlson model). In this case, abnormal earnings (earnings minus cost of book capital) can be thought of as an attribute investors value; an informational link to earnings is not required. Amir, Harris and Venutti (1993) use this approach in a relative association study. Twenty-nine studies in Table 1 use the Ohlson model as motivation for specification of their empirical tests, but only 15 use the specification that includes both earnings and book value as independent variables. The others regress returns on earnings and earnings changes.

\subsection{Balance sheet model}

\subsubsection{Valuation model}

In its levels form, the balance sheet model for an incremental association study takes the following form:

$$
\text { MVE }=\text { MVA }+ \text { MVL }+ \text { MVC }
$$

Where 


$$
\begin{aligned}
\text { MVE }= & \text { market value of equity } \\
\text { MVA }= & \text { market value of separable assets other than the component whose } \\
& \text { incremental association is being assessed } \\
\text { MVL = } & \text { market value of separable liabilities other than the component whose } \\
& \text { incremental association is being assessed (liabilities are assumed to be } \\
& \text { negative values) } \\
\text { MVC = } & \text { market value of the balance sheet component whose incremental } \\
& \text { association is being assessed. }
\end{aligned}
$$

As noted, this model holds if the firm is earning a competitive rate of return on its net assets. The future cash flows, discounted using the appropriate cost of capital, equal the net asset values.

If the firm has some competitive advantage (e.g., proprietary technology that may not be separable and saleable) that allows it to earn a positive abnormal return (rents), then equation (1) does not hold. The equity value exceeds the net assets value. Then equity value is a weighted average of operations value (the value from continuing operations plus the value of future expansion options), and abandonment value (net asset value) (see Berger and Ofek, 1996; Burgstahler and Dichev, 1997; and Wysocki, 1999). Ignoring agency costs, the firm would liquidate (abandon) when the net assets value exceeds the operations value of the firm. With rents, the relevance of net assets depends on the likelihood of abandonment. If the likelihood of abandonment is effectively zero, the value of net assets is not associated with the value of the firm except to the extent it affects future operating cash flows (for example, when replacing assets). If operations value exceeds net assets but there is a likelihood of abandonment then equity value is an increasing convex function of net assets. It is also an increasing convex function of operations value (see Wysocki, 1999, p. 17).

Many incremental association studies using the balance sheet model allow for the possibility that firms have a competitive advantage. For example, value-relevance studies for banks recognize that bankers might earn rents on core deposits (e.g., Eccher, Ramesh and Thiagarajan, 1996). To allow for the fact that equation (1) does not hold with rents, some value-relevance researchers convert it to an identity by including a goodwill term that is defined as the difference between market value of equity and net 
assets value:

$$
\mathrm{MVE} \equiv \mathrm{MVA}+\mathrm{MVL}+\mathrm{MVC}+\mathrm{GW}
$$

Where

$$
\mathrm{GW}=\text { goodwill }
$$

The introduction of goodwill makes equation (2) hold tautologically. It is defined as:

$$
\text { GW } \equiv \text { MVE-MVA-MVL-MVC }
$$

In these cases, independent variables are often included in the regression to proxy for goodwill, but goodwill is not a separable asset, being merely the difference between MVE and the other variables.

\subsubsection{Links to accounting numbers}

If the balance sheet model holds (i.e., there are no rents) the links between the accounting numbers and the valuation model variables are relatively apparent. The variables are the market values of assets and liabilities. It is assumed that each accounting asset or liability number could provide information on the asset or liability's market value. For each asset or liability there should be an accounting number and a market value. In practice, some assets that are separable and marketable are not recorded as an accounting asset (sometimes for non-information reasons such as tax effects, for example the development expense in Amir and Lev, 1996). Also an accounting asset can be recorded for an item that is not a separable and marketable asset (i.e., purchased goodwill). If the balance sheet model does not hold (i.e., there are rents) the links to the accounting numbers become more difficult.

\subsubsection{Implications for incremental association studies}

Coefficient of component being assessed. Non-measurement studies assess the MVC's value-relevance by testing whether its estimated coefficient in equation (1) is significantly different from zero. For an asset, the test might be that the coefficient is significantly positive and for a liability that it is significantly negative.

The presence of rents could affect the sign of the coefficient of an asset or liability. For example, consider a firm where abandonment has effectively a zero probability. Then unless an asset's value is correlated with the omitted rents, its 
coefficient could be zero rather than positive. If the asset value is correlated with future cash flows the expected sign could be negative or positive. Suppose the asset price is determined by the demand from another industry. Then an increase in that asset value could represent higher cash outflows in the future to purchase the asset and be negatively correlated with future cash flows.

Measurement studies typically predict that the coefficients of assets should be one and those of liabilities should be minus one. The extent to which the coefficients differ from one or minus one is used to assess the extent to which accounting numbers measure the market values of assets or liabilities with error (see Barth, 1991; Barth, Beaver and Landsman, 1996; and Eccher, Ramesh and Thiagarajan, 1996). This approach relies on strong assumptions about the bias with which the accounting numbers measure the underlying attributes, the correlation between the measurement errors and the underlying attributes, and the correlation between the measurement errors and other variables in the regression (see Lambert, 1996). Even if these conditions are met, the procedure will fail in the presence of rents because the coefficients of assets and liabilities are not likely to be one and minus one respectively. Equation (1) does not hold and equity value is a nonlinear function of net assets so one wouldn't predict that the coefficients would be one and minus one. Further, the coefficient would vary across firms with the likelihood of abandonment.

Correlated omitted variables. Even if there are no rents, equation (1) requires the inclusion of all asset and liability market values. Often some of those asset and liability values are not included in the regression equation (see Lys, 1996, p. 161). As is recognized in several studies, if the omitted values are correlated with the included values, the estimated coefficients of the included values can be biased from their predicted values of one and minus one. The existence of rents creates a further opportunity for the problem of correlated variables. If no proxies are included for rents (equation 1 is estimated), some of the included assets and liabilities can be correlated with rents. For example, if banks invest in loans where they have informational advantages, rents could be correlated with the market value of those loans (see the discussion in Eccher, Ramesh and Thiagarajan, 1996, p. 85). Even if proxies are included for rents, if those proxies do not account for all of the variation in rents and if 
included asset or liability variables are correlated with rents, the estimated asset and liability coefficients will be biased.

Assessing the value-relevance of assets that are proposed to be included in the balance sheet, or disclosed for the first time, illustrates the linking difficulties that arise with both omitted assets and rents. For example, Eccher, Ramesh and Thiagarajan (1996) assess the value-relevance of the market value of items that are currently not recorded on the balance sheet and whose market values are not currently disclosed (OBS items). Those items include credit-related instruments (e.g., letters of credit) for which the fair value is not available. Eccher et al (1996) are forced to use notional values for those credit instruments. As Eccher et al (1996) recognize, those notional values are likely to be correlated both with the fair values of the instruments and (because they are related to future revenues) with future cash flows. Hence, Eccher et al (1996) cannot predict a sign for the coefficient of the credit-related instruments' value in an incremental relevance study and, if the coefficient is significant, cannot tell whether it is due to the instruments' value and/or expected rents.

\subsection{Earnings model}

\subsubsection{Valuation model}

In relative association studies stock returns are often regressed on alternative measures of earnings. The measure whose regression has the highest $\mathrm{R}^{2}$ is considered the best performance measure or most value relevant. These studies compare income measures within a country (e.g., Dhaliwal, Subramanyam and Trezevant, 1999, comparing measures of comprehensive income to net income) or net income measures across countries (e.g., Barth and Clinch, 1996). In incremental association studies, the market value of equity is often regressed on components of earnings. For example, Barth, Beaver and Landsman (1992) regress the market value of equity on earnings components to assess the incremental value-relevance of pension cost components. These studies imply earnings are related to stock market value or changes in value, but in many cases the valuation model is not explicitly specified.

Generally, the measurement studies specify an explicit valuation model. In those studies involving regressions of equity market value on earnings the earnings coefficient 
is expected to be $1 / \mathrm{r}$, where $r$ is the discount rate for future earnings (e.g., Barth, Landsman and Wahlen, 1995). Similarly when the stock rate of return is regressed on earnings components or changes in earnings components, the equivalent predicted coefficient for earnings or earnings change before the component (deflated by opening price) is $1 / \mathrm{r}$, or close to $1 / \mathrm{r}$, (e.g., Barth, 1994). In these studies, earnings are viewed as "permanent" earnings or the "long run" earnings power of the firm and price is viewed as capitalized earnings (see Barth, Landsman and Wahlen, 1995, p. 586).

"Permanent earnings" is just capitalized earnings converted to a perpetuity. Permanent earnings are equivalent to the transformation of net present value to equivalent annual cost or uniform annual cash flow (see Brealey and Myers, 1996, p. 128). As such, it is a transformation of the estimate of value, not the underlying valuation model - it provides no indication of the attributes that are valued. The primary valuation model is discounted dividends. The discounted earnings model is just a re-expression of the dividend model using the dividend payout assumption (see Beaver, 1998).

The non-measurement relative association studies are consistent with the assumption that earnings measure (or are a transformation of) permanent income since the criterion is $R^{2}$. The lower the error with which earnings measure permanent earnings (a transformation of value), the higher the $\mathrm{R}^{2}$ from the regression of value on earnings.

The equality of current earnings and permanent earnings can be achieved by assuming that the time series of future earnings follow a random walk. However, such an assumption would be inconsistent with empirical evidence for the US. We know that earnings changes are transient for extreme earnings, perhaps because of the abandonment option (e.g., Hayn, 1995) or conservatism (e.g., Basu, 1997). Note also that the transience of extreme earnings implies a non-linear relation between returns and earnings and there is ample evidence to support that implication (e.g., Freeman and Tse, 1992). This non-linearity is not reflected in the regressions used in the literature.

\subsubsection{Links to accounting numbers}

There is no equivalent to permanent income under current GAAP. Yet the numbers employed in the earnings model (some version of earnings) in relative association studies are assumed to represent permanent income or the methodology is 
consistent with that assumption. The use of the value-relevance earnings criterion based on the permanent income concept as the sole criterion to set accounting standards, would result in an earnings number that is associated with value (see section 2). But, the earnings model provides no theory as to what should be in earnings itself, or what should be its important components because permanent earnings is just a transformation of value. The model provides no theory of accounting and when combined with the valuerelevance criterion, is purely a mechanical procedure for producing an earnings number that is highly correlated with value (non-measurement studies) or is a measure of value (measurement studies). Use of this mechanical criterion in an unfettered fashion by standard setters could actually remove the ability of accounting information to provide new information to capital market participants.

\subsubsection{Implications for association studies}

Lack of guidance for earnings and its components. Because it has no theory of accounting, the earnings model provides no guidance to researchers (or standard-setters) as to what numbers should be included in earnings, other than highly associated with value or return. Lacking guidance from a theory, researchers investigate earnings numbers or components of earnings calculated according to existing or proposed standards. This is poses a conundrum for the value relevance literature: proposed standards are often generated on grounds other than value-relevance (see Leftwich, 1995 for an investigation of agenda-setting for the FASB) but value relevance studies evaluate them on the value-relevance criterion.

When the earnings model is used to determine components of earnings (incremental association studies), the incremental association depends on the other numbers in the regression. Because no guidance is provided as to how to sequence the investigations of components, the sequence of investigation for the US depends on what components the researcher chooses to include, and the sequence in which different accounting numbers or components are considered and adopted by the FASB.

Coefficients of earnings and earnings components. The lack of consideration of growth and abandonment option characteristics suggests incorrect predictions for the coefficient of earnings in relative association measurement studies (e.g., the coefficient is 
unlikely to be the predicted function of the discount rate). A similar problem arises for component studies even if the time series properties of components are taken into account (as in Barth, Beaver and Landsman, 1992) because option problems apply to the components as well.

Correlated omitted variables. Some earnings components (such as depreciation) could be positively correlated cross-sectionally with net assets. Hence, they could proxy for the omitted abandonment (and growth) options.

\subsection{Ohlson model}

\subsubsection{Valuation model}

The Ohlson model derives from the residual income valuation model, which takes the following form:

$$
M V E_{o}=B V_{o}+\sum_{t=1}^{\infty}\left\{\left[E_{0}\left(X_{t}\right)-r E_{0}\left(B V_{t-1}\right)\right](1+r)^{-1}\right\}
$$

Where

$\mathrm{MVE}_{0}=$ market value of equity at time 0

$\mathrm{BV}_{\mathrm{t}}=$ book value of equity at time $\mathrm{t}$

$\mathrm{R}=$ investor's opportunity cost of capital

$\mathrm{X} \quad=$ reported earnings

$\mathrm{E}_{\mathrm{t}}=$ expectation operator at time $\mathrm{t}$

The model is derived from the dividend valuation model given clean surplus accounting (change in book value of equity $=$ earnings less dividends plus or minus capital transactions). The model holds for any set of accounting methods as long as the clean surplus condition holds. Changes in future earnings or changing from one set of methods to another are offset by changes in book value. Consequently, like the earnings model, the residual income valuation model per se provides no theory for accounting and no practical prescription for one accounting method over another other than association with value or ability to forecast future earnings (see Coopers \& Lybrand Academic Advisory Committee, 1997).

The residual income valuation model provides a specification of the relation 
between market value and future abnormal earnings (earnings above the required rate of return times the beginning-of-period book value) and the current book value of equity. But those abnormal earnings vary according to the accounting methods used and are unlikely to equal economic abnormal returns (returns greater than the cost of capital times the beginning-of-period market value of net assets). Further, the book value is unlikely to be the market value of net assets.

The Ohlson model replaces the value of future abnormal earnings in the residual income valuation model by current earnings. Ohlson (1995) derives a version of the residual income model that can express market value as a linear function of current earnings, dividends and book value by making assumptions about the behavior of earnings and their relation to information in stock prices (the information dynamics of earnings). Any test of these equations (the Ohlson model) is a joint test of the residual income valuation model and the assumed information dynamics. So, as with the earnings model, variation in association between earnings based on different accounting methods and value, or between different countries' earnings and value, could be due to variation in the extent to which the information dynamics assumptions fit across accounting methods or countries.

The addition of information dynamics does not provide the Ohlson model with an ability for selecting an optimal accounting method. As with the residual income valuation model, a potentially large number of accounting methods fit the model. All that is added to the clean surplus requirement of the more general model is that an appropriate information dynamics must be specified (one in which the future earnings can be expressed in terms of current variables).

While the Ohlson model does lead to the inclusion of the book value of net equity or net assets in the regressions, it does not allow for the existence of options. Book value is there in order to make the equation hold, not to measure the market value of net assets, for purposes of assessing the abandonment option. As with the residual income valuation model, book value in the Ohlson model can be anything (as long as there are offsetting changes in future abnormal earnings). Options will interfere with the linear relations between market value and future earnings and book value and between market value and current earnings, dividends and book value. 
Not only is the Ohlson model inconsistent with an abandonment option, due to the information dynamics assumption it is also inconsistent with firms having expected rents (expected positive net present value projects — see Lo and Lys, 1999, pp. 13-14).

\subsubsection{Links to accounting numbers}

As noted above, like the earnings model, the Ohlson model has no empirical implications for the choice of different accounting procedures. So the only implication comes from the value-relevance literature's methodology, not from the model: choose the procedures that yield book value and earnings numbers that in combination are most highly associated with market value of equity. Coopers \& Lybrand's Academic Advisory Committee (1997) asserts that the model implies that accounting methods should be chosen on the basis of the association of book values with intrinsic values and the prediction of future earnings, but that implication does not flow from the model itself.

\subsubsection{Implications for association studies}

The implications for the Ohlson model are much the same as those for the earnings model. The one difference in the Ohlson model-based studies, is that those studies include a book value term that could cross-sectionally proxy for net assets value and potentially reduce the correlated omitted variables problem (for the omission of net assets).

\section{$5.4 \quad$ Summary}

The valuation models employed in the literature (value-relevance and capital markets) have no role for accounting. The perfect and complete markets assumption that generates the balance sheet model and the competitive capital markets assumption of the discounted dividends model that underlies the earnings and Ohlson models assume costless information. The valuation models supply no theory of accounting.

The assumption that accounting numbers provide information for valuation that underlies the value-relevance literature, by itself, provides very little in the way of a theory of accounting. It cannot explain components of income for example. The only link between accounting numbers and valuation is that the accounting numbers somehow 
provide information on variables in the valuation. Incremental association studies using the balance sheet model often make the link explicit via the assumption of no rents and the assumption that individual accounting assets and liabilities numbers measure their market values implicit in the market value of equity. The no rents assumption, however, is likely not descriptive in many industries and exacerbates correlated omitted variable problems.

The earnings models do not have a link to accounting earnings since permanent earnings is merely a transformation of equity value itself. That means there is no theory to make any predictions about the nature of earnings and their relation to value. The Ohlson model, as employed with current earnings and book value as explanatory variables, assumes no rents. Further, because it is simply a transformation of the discounted dividend model using a clean surplus assumption, the model cannot distinguish between alternative accounting systems. As long as earnings and book value can be transformed to meet the clean surplus assumption the accounting system is consistent with the model.

None of the models can satisfactorily address expansion and growth options. Such options are likely to make relations between accounting variables and value nonlinear. Since all the models are estimated with linear regressions this creates problems for predictions of the coefficients in incremental association studies.

Given these problems, even if providing inputs to valuation were the only role for financial accounting, value-relevance, as it is currently specified, cannot provide much in the way of predictions for accounting practice. Consequently it cannot provide much guidance to standard setters either.

\section{Conclusions and Suggestions for Future Research}

The prime objective of this paper is to assess the value relevance literature's contribution to standard setting. While the existing value relevance literature is large, its contribution to standard setting seems modest. A major reason is that the literature concentrates on equity valuation. Much of the literature is motivated by an assumption that accounting provides inputs to investors' valuations, but the empirical tests amount to 
either associations with equity value or in many cases to equity valuation per se. This conflicts with the FASB's explicit denial that accounting is concerned with providing direct estimates of value and with the nature and history of US accounting practice. Even studies that attempt to indirectly tease out attributes the FASB considers important to accounting numbers (such as relevance and reliability) rely on the extent to which those attributes are reflected in equity market values. Potential differences between the attributes reflected in stock market associations and the FASB's definition of the attributes (e.g., reliability or relevance to another user group) are not explored. And, the indirect nature of the extraction of these attributes, together with the reliance on valuation models inappropriate to most situations, make standard setting inferences questionable in most circumstances (investigation of investment securities held by banks is perhaps one of the most favorable set of circumstances).

Even if the value relevance literature's tests did effectively provide evidence on accounting's role in providing inputs to equity investor valuation, those tests still ignore the other roles of accounting and other forces in the determination of accounting standards and practice. To the extent accounting standards and practice are shaped by other roles and forces that are not perfectly correlated with the valuation role, the value relevance literature misses key attributes of accounting. In this paper, we argue these other forces are substantive and when we examine certain attributes of accounting numbers, we think it is clear that at least some of these other forces are strong and perhaps have become stronger over time. The evidence on conservatism is consistent with that hypothesis.

Conversations with individuals currently and formerly associated with the FASB suggest those individuals are confused about how to interpret the value relevance evidence and how to use it in their deliberations. ${ }^{14}$ While intuitively those individuals, as well as academics, sense something useful must arise from knowing the degree of association between equity valuations and accounting numbers, they find it hard to pinpoint exactly what implications that association has for potential accounting standards.

\footnotetext{
${ }^{14}$ While the FASB clearly tracks academic research and promotes interactions between the board and the academic community (Beresford and Johnson, 1995), they struggle with how to use it in their deliberations (Leisenring and Johnson, 1994).
} 
The points raised in this paper might partially explain why individuals associated with the FASB have difficulty obtaining guidance from the value relevance literature.

Standard setters would be aided if accounting researchers spent more resources investigating the many forces that shape accounting. Moreover, we believe such research would lead to a more fully developed theory of accounting. We worry that many researchers have begun to assume (without supporting evidence) that accounting is predominantly concerned with equity valuation and have lost sight of the other important roles for accounting. ${ }^{15}$ Given our concerns, we use the issues raised in this paper to suggest interesting research topics. We believe that pursuit of the type of research suggested would generate a more descriptive theory of accounting that would aid academics, as well as standard setters, in understanding the forces that shape accounting.

The apparent conservatism of accounting is a phenomenon that is beginning to attract more attention in accounting research (e.g., Basu, 1997; Ball, Kothari and Robin, 1999). Given conservatism's apparent pervasiveness in accounting over time and across countries, increased research into conservatism seems likely to yield significant improvements in understanding accounting. The current assumption of the dominance of the equity valuation role of accounting, suggests it would be informative to investigate whether conservatism can be explained by that role. For example, can the abandonment option explain conservatism (see Hayn, 1995)? Variation in conservatism across countries suggests studies to investigate the reasons for such cross-sectional variation. We have argued that contracting (including stewardship), litigation, political considerations, taxes and other institutional arrangements can influence the degree of conservatism across countries. Does the influence of these factors vary across countries in a way that explains international variation in conservatism? Can the apparent time series variation in conservatism in US accounting, observed in section 4, be explained by variation in these factors? The interaction of standards and practice could be investigated using conservatism as well. Is conservatism due more to how accounting is practiced rather than to the accounting standards enacted? Different factors suggest conservatism

\footnotetext{
${ }^{15}$ There are various forces that might encourage that outcome. For example, with the demise of professional accounting options in leading graduate business schools accounting faculty in those schools have increasingly become involved in teaching valuation. It would not be surprising if faculty members tended to adopt the view that what they teach is central to accounting.
} 
could be more prevalent in some areas of financial reporting than in others. For example, the contracting and tax arguments in section 4 suggest conservatism might play a more important role in financial statement recognition than in disclosure. This suggests a study of the relative conservatism of recognized versus disclosed elements of financial reporting.

Sections 3 and 4 raise other potential research topics involving non-equity valuation roles and other forces affecting accounting and standard setting. Consider non-equity investors (e.g., lenders). What types of accounting information are more relevant for those investors than for equity investors? Some of those issues have been partially investigated in the context of examining typical debt contracts (e.g., Leftwich, 1983) and a start has been made on using accounting information to estimate the abandonment option (e.g., Berger and Ofek, 1996). Is the form and content of the balance sheet largely driven by the demands of these investors as opposed to equity investors? If so, how appropriate is the balance sheet valuation model, as currently implemented, for equity valuation?

Verifiability is also a potentially fruitful research topic. How does verifiability restrict the opportunity set of potential standards? An examination of FASB considerations on verifiability might provide insights into this question.

The influence of the political process on standard setting could also be studied further. For example, can the Leftwich (1995) study on the FASB's agenda setting be extended? Is there any direct evidence that the balance sheet became less useful after the SEC eliminated asset write-ups. Also, could one have predicted the political upheavals associated with the proposed opinion on employee stock options and the hedging and derivatives project (see Foster, 1998)? Under what circumstances do the SEC and Congress become entangled in the standard-setting process? Is it predictable? How do the FASB's votes on issues reflect the political process of standard setting?

While we have concentrated on standard setting implications of this literature, many value relevance studies have an objective beyond providing information for standard setters. In particular, they seek to assess the usefulness of accounting numbers in equity valuation. For example, a question addressed in Barth (1994) is whether fair value disclosures of investment securities can be used to help determine the market value of 
banks' equity securities conditional on the other information included in the model's specifications. This is a pure valuation question. While we have not assessed the overall contribution of the value relevance literature to valuation, many issues we raise in this paper are important for that assessment and for the general valuation literature as well. Contributions to the valuation literature depend on the appropriateness of the valuation models used and the links from the accounting measures to the models (see section 5), as well as the set of conditioning variables (if any) used in the tests. If the conditioning variables are limited in scope, the findings are likely to be less informative.

In section 5 we discuss weaknesses in the current valuation models used in accounting research. In particular, most of the models estimated assume away the existence of economic rents, growth and abandonment options. In addition, most of the estimated models are linear, when there is both ample theory and empirical evidence to support the notion that the relation between the variables in the models and value are non-linear. Thus, another area for future research is to advance the valuation models used in the literature, by explicitly considering rents, growth and abandonment options and the resulting non-linear relations. Again, this is an area where some research is taking place, but there is a surprising reliance on the models highlighted in this review, given those models' weaknesses.

As we have indicated, an important impediment keeping the value relevance literature from contributing more to standard setting debates is its lack of a theory that has some potential to explain accounting and standard setting. As we have seen, assuming accounting involves direct valuation of equity has very little current ability or potential to provide that explanation. Assuming that accounting provides information on inputs to equity and other securities valuation models could, when combined with the other roles of accounting, yield results. It will require more than just an assumption that accounting numbers provide inputs, links between the accounting numbers and valuation models will have to be specified in a way that provides testable implications about accounting. That in turn will require an assumption that information (like contracting) is costly and some way of predicting the information costs and benefits of alternative accounting regimes.

Development and refinement of a descriptive theory of accounting and standard setting will have important implications not only for standard setting but also for the 
accounting valuation literature. ${ }^{16}$ As an example consider the relation between accounting earnings and stock prices. It seems plausible that an accounting theory might predict that the accounting earnings of firms with higher risk and growth measure future cash flows with greater error and bias (see Skinner, 1993, for a contracting explanation of this type or relation). One reason could be that the contracting use of accounting requires verification so accounting earnings do not fully capture growth in firms' future cash flows. The extent to which current earnings capture future cash flows is likely to be smaller for riskier and higher growth firms. ${ }^{17}$ If, for convenience in explanation, we assume the measurement errors in a cross-sectional regression of returns on earnings or changes in earnings are distributed independently of one another and of cash flows, then the coefficients of the earnings variable will incorporate larger downward biases for riskier and higher growth firms. Absent adjustment for this cross-sectional relation implied by accounting theory, the researcher investigating the valuation of accounting earnings could reach incorrect conclusions about the relation between risk and growth and other factors affecting the earnings response coefficient (e.g., the required or market rate of return).

Another example of how accounting theory can impact estimation of value and earnings/value relations comes from the firm's contractual arrangements with various claimholders. Core and Schrand (1999) provide theory and evidence for why the relation between earnings and stock prices will be non-linear as a function of debt indentures that provide the debtholder the right to liquidate the firm. Thus, a non-linearity in the earnings stock price relation is induced by the underlying contracts. This example suggests additional research that examines how the non-valuation roles of accounting (such as contracting) affect the relations between values and accounting measures is warranted.

\footnotetext{
${ }^{16}$ Consistency between accounting theory based on information costs and the valuation model would require valuation models that incorporate the information costs. Given approximate market efficiency the inclusion of information costs is likely to be less important in the valuation model than in the accounting model.

${ }^{17}$ Notice here that we are putting structure on measurement errors just as Barth (1991 and 1994) puts structure on measurement errors. The difference is that we are offering a testable theory as to why that measurement error arises. And, that theory suggests accounting standards are not modified to reduce that error.
} 
The above illustrations of the importance of a descriptive theory of accounting and standard setting to assist standard setters and to the earnings valuation literature demonstrates how such a descriptive theory can help reconcile the two literatures. ${ }^{18}$ It also reinforces our point that one cannot use the valuation literature alone to derive standard setting implications. Given the importance of a descriptive theory of accounting, we encourage the academic community to begin devoting more resources to the types of questions we suggest in this section. In order to advance the accounting literature on multiple fronts and increase the relevance of our research, we must consider all the forces roles that affect the form and content of accounting.

\footnotetext{
${ }^{18}$ See Watts (1992) for discussion of the implications of a descriptive accounting theory for capital markets research, including valuation.
} 


\section{References}

Aboody, D., Lev, B., 1998. The value relevance of intangibles: The case of software capitalization. Journal of Accounting Research 36, 161-191.

Alford. A., Jones, J., Leftwich, R., Zmijewski, M., 1993. The relative informativeness of accounting disclosures in different countries. Journal of Accounting Research Supplement 31, 183-229.

Amir, E., Harris, T.S., Venuti, E.K., 1993. A comparison of value-relevance of US versus non-US-GAAP accounting measures using Form 20-F reconciliations. Journal of Accounting Research Supplement 31, 230-264.

Amir, E., Lev, B., 1996. Value-relevance of nonfinancial information: The wireless communications industry. Journal of Accounting \& Economics 22, 3-30.

Armstrong, M.S., 1977. The politics of establishing accounting standards. Journal of Accountancy 143, 76-79.

Ayers, B.C., 1998. Deferred tax accounting under SFAS No. 109: An empirical investigation of its incremental value-relevance relative to APB No. 11. Accounting Review 73, 195-212.

Ball, R., 1989. The firm as a specialist contracting intermediary: Application to accounting and auditing. Unpublished working paper. University of Rochester.

Ball, R., Kothari, S.P., Robin, A., 1999. The effect of international institutional factors on properties of accounting earnings. Unpublished working paper. University of Rochester.

Ball, R., Robin, A., Wu, J., 2000. Incentives versus standards: Properties of accounting income in four east asian countries, and implications for acceptance of IAS. Unpublished working paper. University of Rochester.

Barth, M.E., 1991. Relative measurement errors among alternative pension asset and liability measures. The Accounting Review 66, 433-463.

Barth, M.E., 1994. Fair value accounting: Evidence from investment securities and the market valuation of banks. Accounting Review 69, 1-25.

Barth, M.E., 2000. Valuation-based accounting research: Implications for financial reporting and opportunities for future research. Accounting and Finance 40, 7-31. 
Barth, M.E., Beaver, W.H., Landsman, W., 1992. The market valuation implications of net periodic pension cost components. Journal of Accounting \& Economics 15, $27-62$.

Barth, M.E., Beaver, W.H., Landsman, W., 1996. Value-relevance of banks' fair value disclosures under SFAS No. 107. The Accounting Review 71, 513-537.

Barth, M.E., Clinch, G., 1996. International accounting differences and their relation to share prices: Evidence from U.K., Australian, and Canadian firms. Contemporary Accounting Research 13, 135-170.

Barth, M.E., Landsman, W.R., Wahlen, J.M., 1995. Fair value accounting: Effects on banks' earnings volatility, regulatory capital, and value of contractual cash flows. Journal of Banking and Finance 19, 577-605.

Barth, M.E., McNichols, M.F., 1994. Studies on accounting, financial disclosures and the law. Journal of Accounting Research 32, 177-209.

Basu, S., 1997. The conservatism principle and the asymmetric timeliness of earnings. Journal of Accounting \& Economics 24, 3-37.

Beaver, W.H., 1998. Financial reporting: An accounting revolution, $2^{\text {nd }}$ edition. Prentice-Hall, Englewood Cliffs, NJ.

Beaver, W.H., Lambert, R., Morse, D., 1980. The information content of security prices. Journal of Accounting \& Economics 2, 23-28.

Beresford, D.R., 1996. What did we learn from the stock compensation project? Accounting Horizons 10, 125-130.

Beresford, D.R., Johnson, L.T., 1995. Interactions between the FASB and the academic community. Accounting Horizons 9, 108-117.

Berger, P.G., Ofek, E., 1996. Bustup takeovers of value-destroying diversified firms. Journal of Finance 51, 1175-1200.

Brealey, R., Myers, S., 1996. Principles of corporate finance, fifth edition, McGraw-Hill, NY.

Brown, P., Izan, H.Y., Loh, A.L., 1992. Fixed asset revaluations and managerial incentives. Abacus 28, 36-57. 
Brown, S., Lo, K., Lys, T., 1999. Use of $\mathrm{R}^{2}$ in accounting research: Measuring changes in value relevance over the last four decades. Journal of Accounting \& Economics 28, 83-115.

Burgstahler, D., Dichev, I., 1997. Earnings management to avoid earnings decreases and losses. Journal of Accounting \& Economics 24, 99-126.

Chang, J., 1999. The decline in value relevance of earnings and book values. Working paper, Harvard University.

Coopers \& Lybrand Academic Advisory Committee, 1997. Evaluating financial reporting standards. Discussion paper.

Core, J.E., Schrand, C.M., 1999. The effect of accounting-based debt covenants on equity valuation. Journal of Accounting \& Economics 27, 1-34.

Dhaliwal, D., Subramanyam, K.R., Trezevant, R., 1999. Is comprehensive income superior to net income as a measure of firm performance? Journal of Accounting \& Economics 26, 43-67.

Dillon, G.J., 1979. Corporate asset revaluations, 1925-1934. The Accounting Historians Journal 6, 1-15.

Eccher, E.A., Ramesh, K., Thiagarajan, S.R., 1996. Fair value disclosures by bank holding companies. Journal of Accounting \& Economics 22, 79-117.

Ely, K., Waymire, G., 1999a. Intangible assets and equity valuation in the pre-SEC era. Unpublished working paper. University of Iowa.

Ely, K., Waymire, G., 1999b. Accounting standard-setting organizations and earningsrelevance: Longitudinal evidence from NYSE common stocks, 1927-93. Journal of Accounting Research 37, 293-317.

Fabricant, S., 1936. Revaluations of fixed assets, 1925-1934. National Bureau of Economic Research. December.

Feltham, J., Ohlson, J.A., 1995. Valuation and clean surplus accounting for operating and financial activities. Contemporary Accounting Research (Spring), 689-731.

Fields, T., Lys, T., Vincent, L., 2000. Empirical research on accounting choice. Unpublished working paper. Northwestern University. 
Financial Accounting Standards Board (FASB), 1980. Statement of Financial

Accounting Concepts No. 2, qualitative characteristics of accounting information. FASB, Norwalk, CT.

Financial Accounting Standards Board (FASB), 1984. Statement of Financial

Accounting Concepts No. 5, Recognition and measurement in financial statements of business enterprises. FASB, Norwalk, CT.

Financial Accounting Standards Board (FASB), 1997. Statement of Financial

Accounting Standards No. 130, Reporting comprehensive income. FASB, Norwalk, CT.

Finney, H.A., 1935. Principles of accounting, volume II. Prentice-Hall, Inc. New York, NY.

Foster, N., 1998. FASB's impact on the cost of capital. FASB Financial Accounting Series No. 182-B, Norwalk, CT.

Freeman, R., Tse, S.Y., 1992. A non-linear model of security price responses to unexpected earnings. Journal of Accounting Research 30, 185-209.

Givoly, D., Hayn, C., 2000. The changing time-series properties of earnings, cash flows and accruals: Has financial reporting become more conservative? Journal of Accounting \& Economics 29, forthcoming.

Guenther, D.A., Maydew, E.L., Nutter, S.E., 1997. Financial reporting, tax costs, and book-tax conformity. Journal of Accounting \& Economics 23, 225-248.

Harris, T.S., Lang, M., Moller, H.P., 1994. The value relevance of German accounting measures: An empirical analysis. Journal of Accounting Research 32, 187-209.

Harris, M.S., Muller, K.A., 1999. The market valuation of IAS versus US-GAAP accounting measures using Form 20-F reconciliations. Journal of Accounting \& Economics 26, 285-312.

Hayn, C., 1995. The information content of losses. Journal of Accounting \& Economics $20,125-153$.

Healy, P., 1985. The effect of bonus schemes on accounting decisions. Journal of Accounting \& Economics 7, 85-107.

Hirst, D.E., Hopkins, P.E., 1998. Comprehensive income reporting and analysts' valuation judgments. Journal of Accounting Research Supplement 36, 47-83. 
Holthausen, R.W., 1981. Evidence on the effect of bond covenants and management compensation contracts on the choice of accounting techniques: The case of the depreciation switch-back. Journal of Accounting \& Economics 3, 73-79.

Holthausen, R.W., Leftwich, R.W., 1983. The economic consequences of accounting choice: Implications of costly contracting and monitoring. Journal of Accounting \& Economics 5, 77-117

Holthausen, R.W., Larcker, D.F., Sloan, R.G., 1995. Annual bonus schemes and the manipulation of earnings. Journal of Accounting \& Economics 19, 29-74.

Holthausen, R.W., Palepu, K., 1994. Research investigating the economic consequences of accounting standards. Unpublished working paper. University of Pennsylvania.

Johnson, L.T., Swieringa, R.J., 1996. Anatomy of an agenda decision: Statement No. 115. Accounting Horizon 10, 149-179.

Kellogg, R., 1984. Accounting activities, security prices, and class action lawsuits. Journal of Accounting \& Economics 6, 185-204.

Kothari, S.P., 2000. Capital markets research in accounting. Unpublished working paper. Massachusetts Institute of Technology.

Kothari, S.P., Lys, T.Z., Smith, C.W., Watts, R.L., 1988. Auditor liability and information disclosure. Journal of Accounting, Auditing and Finance (Fall), 307-339.

Lambert, R.A., 1996. Financial reporting research and standard setting. Unpublished working paper. Stanford University.

Leftwich, R.W., 1981. Evidence of the impact of mandatory changes in accounting principles on corporate loan agreements. Journal of Accounting \& Economics 3, 336.

Leftwich, R.W., 1983. Accounting information in private markets: Evidence from private lending agreements. The Accounting Review 63, 23-42.

Leftwich, R.W., 1995. The agenda of the financial accounting standards board. Unpublished working paper. University of Chicago.

Leisenring, J.J., Johnson, L.T., 1994. Accounting Horizons 8, 4-79.

Lo, K., Lys, T.Z., 1999. The Ohlson model: Contribution to valuation theory, limitations and empirical applications. Unpublished working paper. Northwestern University. 
Lys, T.Z., 1996. Abandoning the transactions-based accounting model: Weighing the evidence. Journal of Accounting \& Economics 22, 155-175.

Ohlson, J.A., 1995. Earnings, book values, and dividends in security valuation. Contemporary Accounting Research 11, 161-182.

Saito, S., 1983. Asset revaluations and cost basis: Capital revaluation in corporate financial reports. The Accounting Historians Journal 10, 1-23.

Skinner, D.J., 1993. The Investment opportunity set and accounting procedure choice. Journal of Accounting \& Economics 16, 407-445.

Skinner, D.J., 1996. Are disclosures about bank derivatives and employee stock options 'value-relevant'? Journal of Accounting \& Economics 22, 393-405.

Skinner, D.J., 1999. How well does net income measure firm performance? A discussion of two studies. Journal of Accounting \& Economics 26, 105-111.

Smith, C.W., Warner, J., 1979. On financial contracting: An analysis of bond covenants. Journal of Financial Economics 7, 117-161.

Smith, C.W., Watts, R.L., 1982. Incentive and tax effects of executive compensation plans. Australian Journal of Management 7, 139-157.

Sweeney, A.P., 1994. Debt-covenant violations and managers' accounting responses. Journal of Accounting \& Economics 17, 281-308.

Venkatachalam, M., 1996. Value-relevance of banks' derivatives disclosures. Journal of Accounting \& Economics 22, 327-355.

Walker, R.G., 1992. The SEC's ban on upward asset revalautions and the disclosure of current values. Abacus 28, 3-35.

Watts, R.L., 1992. Accounting choice theory and market-based research in accounting. British Accounting Review 24, 235-267.

Watts, R.L., 1993. A proposal for research on conservatism. Unpublished working paper. University of Rochester. Presented for discussion at the AAA meetings, San Francisco, CA.

Watts, R.L., Zimmerman, J.L., 1986. Positive accounting theory, Prentice Hall, Englewood Cliffs, NJ.

Wysocki, P.D., 1999. Real options and the informativeness of segment disclosures. Unpublished working paper. University of Michigan. 
Yang, J., 1927. Goodwill and other intangibles. Ronald Press, NY.

Zeff, S. A., 1999, The evolution of the conceptual framework for business enterprises in the United States. The Accounting Historians Journal 26, 89-131. 


\section{Appendix 1}

\section{Value-Relevance Papers}

Aboody, D., 1996. Market valuation of employee stock options. Journal of Accounting \& Economics 22, 357-391.

Aboody, D., Lev, B., 1998. The value relevance of intangibles: The case of software capitalization. Journal of Accounting Research 36, 161-191.

Ahmed, A.S., Takeda, C., 1995. Stock market valuation of gains and losses on commercial banks' investment securities: An empirical analysis. Journal of Accounting \& Economics 20, 207-225.

Alford. A., Jones, J., Leftwich, R., Zmijewski, M., 1993. The relative informativeness of accounting disclosures in different countries. Journal of Accounting Research Supplement 31, 183-229.

Amir, E., 1993. The market valuation of accounting information: The case of postretirement benefits other than pensions. Accounting Review 68, 703-724.

Amir, E., 1996. The effect of accounting aggregation on the value-relevance of financial disclosures: The case of SFAS No. 106. Accounting Review 71, 573-590.

Amir, E., Harris, T.S., Venuti, E.K., 1993. A comparison of value-relevance of US versus non-US-GAAP accounting measures using Form 20-F reconciliations. Journal of Accounting Research Supplement 31, 230-264.

Amir, E., Kirschenheiler, M., Willard, K., 1997. The valuation of deferred taxes. Contemporary Accounting Research 14, 597-622.

Amir, E., Lev, B., 1996. Value-relevance of nonfinancial information: The wireless communications industry. Journal of Accounting \& Economics 22, 3-30.

Anthony, J.H., Petroni, K.R., 1997. Accounting estimation disclosures and firm valuation in the property-casualty insurance industry. Journal of Accounting, Auditing \& Finance 12, 257-281.

Ayers, B.C., 1998. Deferred tax accounting under SFAS No. 109: An empirical investigation of its incremental value-relevance relative to APB No. 11. Accounting Review 73, 195-212. 
Ballas, A., 1997. Valuation implications of the components of earnings: Cross-sectional evidence from Greece. Unpublished working paper, Athens Greece.

Balsam, S., Lipka, R., 1998. Share prices and alternative measures of earnings per share. Accounting Horizons 12, 234-249.

Bandyopadhay, S.P., Hanna, J.D., Richardson, G., 1994. Capital market effects of USCanada GAAP differences, Journal of Accounting Research 32, 262-277.

Barth, M.E., 1991. Relative measurement errors among alternative pension asset and liability measures. The Accounting Review 66, 433-463.

Barth, M.E., 1994. Fair value accounting: Evidence from investment securities and the market valuation of banks. Accounting Review 69, 1-25.

Barth, M.E., Beaver, W.H., Landsman, W., 1992. The market valuation implications of net periodic pension cost components. Journal of Accounting \& Economics 15, 2762.

Barth, M.E., Beaver, W.H., Landsman, W., 1996. Value-relevance of banks' fair value disclosures under SFAS No. 107. The Accounting Review 71, 513-537.

Barth, M.E., Beaver, W.H., Stinson, C.H., 1991. Supplemental data and the structure of thrift share prices. Accounting Review 66, 56-66.

Barth, M.E., Clement, M., Foster, G., Kasznik, R., 1998. Brand values and capital market valuation. Review of Accounting Studies 3, 41-68.

Barth, M.E., Clinch, G., 1996. International accounting differences and their relation to share prices: Evidence from U.K., Australian, and Canadian firms. Contemporary Accounting Research 13, 135-170.

Barth, M.E., Clinch, G., 1998. Revalued financial tangible, and intangible assets: Associations with share prices and non market-based value estimates. Journal of Accounting Research 36, 199-233.

Barth, M.E., McNichols, M.F., 1994, Estimation and market valuation of environmental liabilities relating to superfund sites. Journal of Accounting Research Supplement 32, 177-209.

Bartov, E., 1997. Foreign currency exposure of multinational firms: Accounting measures and market valuation. Contemporary Accounting Research 14, 623-652. 
Beaver, W.H., Christie, A.A., Griffin, P.A., 1980. The information content of SEC accounting series release No. 190. Journal of Accounting \& Economics 2, 127-

Beaver, W.H., Dukes, R.E., 1972. Interperiod tax allocation earnings expectations, and the behavior of security prices. Accounting Review 47, 320-418.

Biddle, G.C., Bowen, R.M., Wallace, J.S., 1997. Does EVA beat earnings? Evidence on associations with stock returns and firm values. Journal of Accounting \& Economics 24, 301-336.

Black, E.L., 1998. Life-cycle impacts on the incremental value-relevance of earnings and cash flow measures. Journal of Financial Statement Analysis 4, 40-56.

Bodnar, G.M., Weintrop, J., 1997. The valuation of the foreign income of US multinational firms: A growth opportunities perspective. Journal of Accounting \& Economics 24, 69-97.

Chan, K.C., Seow, G.S., 1996. The association between stock returns and foreign GAAP earnings vs. earnings adjusted to US GAAP. Journal of Accounting \& Economics 21, 139-158.

Chaney, P.K., Jeter, D.C., 1994. The effect of deferred taxes on security prices. Journal of Accounting, Auditing \& Finance 9, 91-116.

Cheng, C.S.A., Liu, C., Schaefer, T.F., 1997. The value-relevance of SFAS No. 95 cash flows from operations as assessed by security market effects. Accounting Horizons 11, 1-15.

Choi, B., Collins, D.W., Johnson, W.B., 1997. Valuation implications of reliability differences: The case of nonpension postretirement obligations. Accounting Review 72, 351-383.

D’Souza, J., Jacob, J., Soderstrom, N.S., 2000. Nuclear decommissioning costs: The impact of recoverability risk on valuation. Journal of Accounting \& Economics 29, forthcoming.

Davis-Friday, P.Y., Rivera, J.M., 2000. Inflation accounting and 20-F disclosures: Evidence from Mexico. Accounting Horizons 14, 114-135.

Dhaliwal, D., Subramanyam, K.R., Trezevant, R., 1999. Is comprehensive income superior to net income as a measure of firm performance? Journal of Accounting \& Economics 26, 43-67. 
Eccher, E.A., Ramesh, K., Thiagarajan, S.R., 1996. Fair value disclosures by bank holding companies. Journal of Accounting \& Economics 22, 79-117.

Ely, K., Waymire, G., 1999. Intangible assets and equity valuation in the pre-SEC era. Unpublished working paper. University of Iowa.

Fields, T.D., Rangan, S., Thiagarajan, S.R., 1998. An empirical evaluation of the usefulness of non-GAAP performance measures in the REIT industry. Review of Accounting Studies 3, 103-130.

Francis, J., Schipper, K., 1999. Have financial statements lost their relevance? Journal of Accounting Research 37, 319-352.

Gheyara, K., Boatsman, J., 1980. Market reaction to the 1976 replacement cost disclosures. Journal of Accounting \& Economics 2, 107-125.

Givoly, D., Hayn, C., 1992. The valuation of the deferred tax liability: Evidence from the stock market. Accounting Review 67, 394-410.

Gopalakrishnan, V., 1994. The effect of recognition vs. disclosure on investor valuation: The case of pension accounting. Review of Quantitative Finance \& Accounting 4, 383-396.

Gopalakrishnan, V., Sugrue, T.F., 1993. An empirical investigation of stock market valuation of corporate projected pension liabilities. Journal of Business Finance \& Accounting 20, 711-724.

Graham, R.C., Lefanowicz, G.C., Petroni, K.R., 1998. Value-relevance of fair value disclosures for investments in securities accounted for under the equity method. Unpublished working paper, Michigan State University.

Harris, M.S., Muller, K.A., 1999. The market valuation of IAS versus US-GAAP accounting measures using Form 20-F reconciliations. Journal of Accounting \& Economics 26, 285-312.

Harris, T.S., Lang, M., Moller, H.P., 1994. The value relevance of German accounting measures: An empirical analysis. Journal of Accounting Research 32, 187-209.

Harris, T.S., Ohlson, J.A., 1987. Accounting disclosures and the market's valuation of oil and gas properties. Accounting Review 62, 651-670.

Henning, S.L., Stock, T., 1997. The value-relevance of goodwill write-offs. Unpublished working paper, Southern Methodist University. 
Hirschey, M., Richardson, V.J., Scholz, S.W., 1998. Value-relevance of nonfinancial information: The case of patent data. Unpublished working paper, University of Kansas.

Joos, P., Lang, M., 1994. The effects of accounting diversity: Evidence from the European Union. Journal of Accounting Research Supplement 32, 141-175.

Lev, B., Sougiannis, T., 1996. The capitalization, amortization, and value-relevance of R\&D. Journal of Accounting \& Economics 21, 107-138.

Nelson, K.K., 1996. Fair value accounting for commercial banks: An empirical analysis of SFAS No. 107. Accounting Review 71, 161-182.

Petroni, K.R., Wahlen, J.M., 1995. Fair values of equity and debt securities and share prices of property-liability insurers. Journal of Risk and Insurance 62, 719-737.

Pope, P.F., Rees, W., 1993. International differences in GAAP and the pricing of earnings. Journal of International Financial Management and Accounting 4, 190219.

Rees, L., Elgers, P., 1997. The market's valuation of nonreported accounting measures: Retrospective reconciliations of non-U.S. and U.S. GAAP. Journal of Accounting Research 35, 115-127.

Rees, L., Stott, D., 1999. The value-relevance of stock-based employee compensation disclosures. Unpublished working paper, Texas A \& M University.

Shevlin, T., 1991. The valuation of R\&D firms with R\&D limited partnerships. Accounting Review 66, 1-21.

Venkatachalam, M., 1996. Value-relevance of banks' derivatives disclosures. Journal of Accounting \& Economics 22, 327-355.

Vincent, L., 1997. Equity valuation implications of purchase versus pooling accounting. Journal of Financial Statement Analysis 2, 5-20.

Vincent, L., 1999. The information content of funds from operations (FFO) for real estate investment trusts (REITs). Journal of Accounting \& Economics 26, 69-104.

Whisenant, J.S., 1998. Does fundamental analysis produce more value-relevant summary measures? Unpublished working paper, Georgetown University. 
Table 1

Value-relevance papers classified by methodology and motivation Methodology Standard-Setting Motivation

\begin{tabular}{|c|c|c|c|c|c|c|c|c|c|}
\hline \multirow[b]{3}{*}{ No. } & \multirow[b]{3}{*}{ Author(s) } & \multirow[b]{3}{*}{ Journal } & \multirow[b]{3}{*}{ Year } & \multicolumn{4}{|c|}{ Methodology } & \multicolumn{2}{|c|}{ Standard-Setting Motivation } \\
\hline & & & & Relative & Incremental & $\begin{array}{c}\text { Marginal } \\
\text { Information }\end{array}$ & & & \\
\hline & & & & Association & AssociationMeasuremen & Content & ntertemporal & Explicit & Implicit \\
\hline 1 & Aboody & JAE & 1996 & & 1 & & & 1 & \\
\hline 2 & Aboody \& Lev & JAR & 1998 & & 1 & & & 1 & \\
\hline 3 & Ahmed \& Takeda & JAE & 1995 & & 1 & & & 1 & \\
\hline 4 & Alford, Jones, Leftwich \& Zmijews] & JAR & 1993 & 1 & & & & 1 & \\
\hline 5 & Amir & AR & 1993 & & 1 & & & 1 & \\
\hline 6 & Amir & AR & 1996 & & 1 & & & 1 & \\
\hline 7 & Amir, Harris \& Venuti & JAR & 1993 & & 1 & 1 & & 1 & \\
\hline 8 & Amir, Kirschenheiter \& Willard & CAR & 1997 & & 1 & & & 1 & \\
\hline 9 & Amir \& Lev & JAE & 1996 & & 1 & 1 & & & 1 \\
\hline 10 & Anthony \& Petroni & JAAF & 1997 & & 1 & & & 1 & \\
\hline 11 & Ayers & $\mathrm{AR}$ & 1998 & & 1 & & & 1 & \\
\hline 12 & Ballas & WP & 1997 & & 1 & & 1 & 1 & \\
\hline 13 & Balsam \& Lipka & $\mathrm{AH}$ & 1998 & 1 & 1 & & 1 & 1 & \\
\hline 14 & Bandyopadhyay, Hanna \& Richards & JAR & 1994 & & 1 & 1 & & 1 & \\
\hline 15 & Barth & AR & 1991 & & 1 & & & 1 & \\
\hline 16 & Barth & AR & 1994 & & 1 & & & 1 & \\
\hline 17 & Barth, Beaver \& Landsman & JAE & 1992 & & 1 & & & 1 & \\
\hline 18 & Barth, Beaver \& Landsman & $\mathrm{AR}$ & 1996 & & 1 & & & 1 & \\
\hline 19 & Barth, Beaver \& Stinson & $\mathrm{AR}$ & 1991 & & 1 & & & 1 & \\
\hline 20 & Barth, Clement, Foster \& Kasznik & RAS & 1998 & & 1 & & & & 1 \\
\hline 21 & Barth \& Clinch & CAR & 1996 & & 1 & & & 1 & \\
\hline 22 & Barth \& Clinch & JAR & 1998 & & 1 & & & 1 & \\
\hline 23 & Barth \& McNichols & JAR & 1994 & & 1 & & & 1 & \\
\hline 24 & Bartov & CAR & 1997 & & 1 & & & 1 & \\
\hline 25 & Beaver, Christie \& Griffin & JAE & 1980 & & & 1 & & 1 & \\
\hline 26 & Beaver \& Dukes & $\mathrm{AR}$ & 1972 & 1 & & & & 1 & \\
\hline 27 & Biddle, Bowen \& Wallace & JAE & 1997 & 1 & 1 & & & 1 & \\
\hline 28 & Black & JFSA & 1998 & & 1 & & & & 1 \\
\hline 29 & Bodnar \& Weintrop & JAE & 1997 & 1 & 1 & & & & 1 \\
\hline 30 & Chan \& Seow & JAE & 1996 & 1 & & & & 1 & \\
\hline 31 & Chaney \& Jeter & JAAF & 1994 & & 1 & & & 1 & \\
\hline 32 & Cheng, Liu \& Schaefer & $\mathrm{AH}$ & 1997 & & 1 & & & 1 & \\
\hline 33 & Choi, Collins \& Johnson & $\mathrm{AR}$ & 1997 & & 1 & & & 1 & \\
\hline 34 & D'Souza, Jacob, Soderstrom & JAE & 2000 & & 1 & & & & 1 \\
\hline 35 & Davis-Friday, Rivera & $\mathrm{AH}$ & 2000 & & 1 & & & 1 & \\
\hline 36 & Dhaliwal, Subramanyam \& Trezeva & JAE & 1999 & 1 & & & & 1 & \\
\hline 37 & Eccher, Ramesh \& Thiagarajan & JAE & 1996 & & 1 & & & 1 & \\
\hline 38 & Ely \& Waymire & WP & 1999 & & 1 & & & 1 & \\
\hline 39 & Fields, Rangan \& Thiagarajan & RAS & 1998 & 1 & 1 & & & 1 & \\
\hline 40 & Francis \& Schipper & JAR & 1999 & & & & 1 & 1 & \\
\hline 41 & Gheyara \& Boatsman & JAE & 1980 & & & 1 & & 1 & \\
\hline 42 & Givoly \& Hayn & $\mathrm{AR}$ & 1992 & & & 1 & & 1 & \\
\hline 43 & Gopalakrishnan & RQFA & 1994 & & 1 & & & 1 & \\
\hline 44 & Gopalakrishnan \& Sugrue & JBFA & 1993 & & 1 & & & 1 & \\
\hline 45 & Graham, Lefanowicz \& Petroni & WP & 1998 & & 1 & & & 1 & \\
\hline 46 & Harris \& Muller & JAE & 1999 & 1 & 1 & & 1 & 1 & \\
\hline 47 & Harris, Lang \& Moller & JAR & 1994 & 1 & 1 & & & 1 & \\
\hline 48 & Harris \& Ohlson & $\mathrm{AR}$ & 1987 & 1 & 1 & & & 1 & \\
\hline 49 & Henning \& Stock & WP & 2000 & & 1 & & & 1 & \\
\hline 50 & Hirschey, Richardson \& Scholz & WP & 1998 & & 1 & & & 1 & \\
\hline 51 & Joos \& Lang & JAR & 1994 & 1 & & & 1 & 1 & \\
\hline 52 & Lev \& Sougiannis & JAE & 1996 & & 1 & & & 1 & \\
\hline 53 & Nelson & $\mathrm{AR}$ & 1996 & & 1 & & 1 & 1 & \\
\hline 54 & Petroni \& Wahlen & JRI & 1995 & & 1 & & & 1 & \\
\hline 55 & Pope \& Rees & JIFMA & 1993 & 1 & 1 & & & 1 & \\
\hline 56 & Rees \& Elgers & JAR & 1997 & & 1 & & & 1 & \\
\hline 57 & Rees \& Stott & WP & 1999 & & 1 & & 1 & 1 & \\
\hline 58 & Shevlin & $\mathrm{AR}$ & 1991 & & 1 & & & 1 & \\
\hline 59 & Venkatachalam & JAE & 1996 & & 1 & & & & 1 \\
\hline 60 & Vincent & JFSA & 1997 & & 1 & & & & 1 \\
\hline 61 & Vincent & $\mathrm{JAE}$ & 1999 & 1 & 1 & 1 & & 1 & \\
\hline 62 & Whisenant & WP & 1998 & 1 & 1 & & & & 1 \\
\hline & TOTAL & & & 15 & 53 & 7 & 7 & 54 & 8 \\
\hline
\end{tabular}


Journal Abbreviations

$\mathrm{ABR}=$ Accounting and Business Research

$\mathrm{AER}=$ American Economic Review

$\mathrm{AFE}=$ Applied Financial Economics

$\mathrm{AF}=$ Accounting and Finance

$\mathrm{AH}=$ Accounting Horizons

AQAFA = Advances in Quantitative Analysis of Finance \& Accountin

$\mathrm{AR}=$ Accounting Review

$\mathrm{BAF}=$ Bank Accounting and Finance

$\mathrm{CAR}=$ Contermporary Accounting Research

FAJ $=$ Financial Analyst Journal

FASB $=$ Financial Accounting Standards Board

IJA = International Journal of Accounting

JAAF = Journal of Accounting, Auditing and Finance
$\mathrm{JAE}=$ Journal of Accounting \& Economics

$\mathrm{JAL}=$ Journal of Accounting Literature

$\mathrm{JAR}=$ Journal of Accounting Research

$\mathrm{JBF}=$ Journal of Banking and Finance

$\mathrm{JBFA}=$ Journal of Business Finance and Accounting

$\mathrm{JEB}=\mathrm{J}$ Journal of Economics and Business

JREPM = Journal of Real Estate Portfolio Management

JFSA = Journal of Financial Statement Analysis

JIFMA = Journal of International Financial Management \& Accounting

$\mathrm{JRI}=$ Journal of Risk and Insurance

MA = Management Accounting

RAS $=$ Review of Accounting Studies

RQFA = Review of Quantitative Finance \& Accounting

$\mathrm{WP}=$ Working Paper (included only if publication not found) 
Table 2

Comparison of conservatism of US income numbers over time

by reporting regime,1927-1993

Average coefficients from yearly cross-sectional regressions of earnings on contemporaneous returns for different reporting regimes (Ely \& Waymire Data), coefficients from pooled cross-sectional regressions of earnings on contemporaneous returns with dummies for different reporting regimes (Basu, 1997), coefficients from pooled cross-sectional regressions of earnings on contemporaneous returns (Ball, Kothari \& Robin, 1999)

$X_{t} / P_{t: 1}=\alpha_{0}+\alpha_{1} D R_{t}+\beta_{0} R_{t}+\beta_{1} D R_{t} R_{t}$

\begin{tabular}{ccc}
\multicolumn{3}{c}{ EARNINGS REGRESSION } \\
Mean coefficient of \\
Loss & \multicolumn{1}{c}{ Dummy* } \\
Dummy & Return & Return \\
$\alpha_{1}$ & $\beta_{0}$ & $\beta_{1}$ \\
& & Conservatism
\end{tabular}

OPERATING EARNINGS REGRESSION

Mean coefficient of

Dummy Return Return

$\begin{array}{lll}\alpha_{1} & \beta_{0} & \beta_{1}\end{array}$

$\beta_{1}$

ELY \& WAYMIRE DATA

Average of individual year regressions

Subperiod

Reporting regime

1927.41

Prestandard-setting, low litigation

0.00

1942.46

Price controls, standard-setting, low litigation

$(0.48)$
0.07

$0.11^{* *}$

$(5.57)$
$0.60^{* *}$

$(8.16) \quad(.98)$

$\begin{array}{lll}0.03 & 0.33^{* *} & 0.01\end{array}$

1947.50

Standard-setting, low litigation

$\begin{array}{ccc}(1.39) & (6.54) & (0.10) \\ 0.03 & 0.22^{* *} & 0.07\end{array}$

$\begin{array}{lll}(2.24) & (5.38) & (1.66)\end{array}$

$\begin{array}{ccc}0.00 & 0.08^{* *} & 0.06^{*} \\ (0.51) & (6.78) & (2.61)\end{array}$

$\begin{array}{lll}(0.51) & (6.78) & (2.61) \\ 0.03^{*} & 0.11^{* *} & 0.05^{* *}\end{array}$

$\begin{array}{lll}0.03^{*} & 0.11^{* *} & 0.05^{* *} \\ (2.13) & (5.58) & (3.62)\end{array}$

$0.03^{*} \quad 0.14^{* *} \quad 0.16^{* *}$

(2.13) (6.49) (3.40)

$\begin{array}{lll}0.02 & 0.00 & 0.43 * *\end{array}$

$\begin{array}{lll}0.89) & (0.63) & (7.47)\end{array}$

$\begin{array}{ccc}0.00 & .06 * * & 0.04 \\ (0.73) & (4.67) & (1.34)\end{array}$

(0.73) (4.67) (1.34)

Full period

Standard-setting, low litigation

1927.93

$\begin{array}{ccc}.02 * * & 0.14 * * & 0.10^{* * *} \\ (3.44) & (14.99) & (7.77)\end{array}$

$\begin{array}{lccc}0.10 * * & 0.00 & 0.36 * * & -0.06 \\ (7.77) & (2.85) & (13.87) & (3.45)\end{array}$

.0 .09

$\begin{array}{lll}0.07 & 2.29 * * & -1.53 \\ (0.04) & (5.69) & (-1.05) \\ 0.05 & 0.71 * * & .0 .16\end{array}$

$0.05 \quad 0.71^{* *} \quad-0.16$

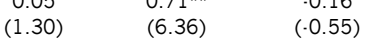

$\begin{array}{cc}(6.36) & (-0.55) \\ 0.49 * * & 0.05\end{array}$

$0.49^{* *} \quad 0.05$

$\begin{array}{ccc}(1.89) & (5.64) & (-0.55) \\ 0.01 & 0.18^{* *} & 0.08^{*} \\ (1.34) & (6.52) & (2.30)\end{array}$

$\begin{array}{lll}(1.34) & (6.52) & (2.30) \\ 0.02 & 0.08^{* *} & 0.08^{*}\end{array}$

$\begin{array}{ll}0.08^{* *} & 0.08^{*} \\ (3.39) & (2.42)\end{array}$

$\begin{array}{ccc}(1.43) & (3.39) & (2.42) \\ 0.06 & 0.26 & 0.02\end{array}$

(0.68) (0.06) (1.59)

$0.03^{*} \quad 0.08^{* *} \quad 0.32^{* *}$

$\begin{array}{lll}0.03^{*} & 0.08^{* *} & 0.32^{* *} \\ (2.30) & (3.19) & (5.32)\end{array}$

$\begin{array}{lll}(2.30) & (3.19) & (5.32) \\ 0.03 & 0.19 * & 0.09\end{array}$

$\begin{array}{lll}0.03 & (3.62) & (1.78)\end{array}$

BASU (1997)

Pooled cross-sectional regressions with regime dummies

1963.66

1967.75 Standard-setting, high litigation

1976.82 Standard-setting, litigation

1983.90 Standard-setting, high litigation

$\begin{array}{ccc}0.00 & 0.03^{* *} & 0.01 \\ (0.01) & (4.74) & (0.93) \\ 0.02 & 0.07 & 0.19 \\ .0 .01 & 0.03 & 0.19 \\ 0.03 & 0.03 & 0.40\end{array}$

EARNINGS BEFORE EXTRAORDINARY ITEMS

BALL,KOTHAR \& ROBIN (1999)

Pooled cross-sectional regressions

1985.90 Standard-setting, high litigation

1991.95

Standard-setting, high litigation

$\begin{array}{lll}? & 0.03^{* *} & 0.29^{* *} \\ ? & (6.14) & (26.79) \\ & 0.03^{* *} & 0.33^{* *} \\ & (6.54) & (22.14)\end{array}$

t-statistics in parentheses. For the Ely \& Waymire data the t-statistics are for the mean coefficient. No t-statistics are available for the last three Basu periods because the coefficients are obtained from aggregating reported coefficients.

Ely \& Waymire Data. Sample of 100 firms drawn randomly each year in the period 1927.1993 that met two criteria: I) stock price data available from CRSP Monthly Price File for 29 months from February of the prior year through June of the subsequent year; and 2) four-digit SIC code between 1000 and 3999 . Earnings are from Compustat or Moody's Industrial Manuals. Earnings data are not available for 30 of the 6700 firm years and those observations are not replaced. As a result the yearly number of observations varies from 97.100 with most of the missing data occurring pre-1951.

Basu's sample consists of 43,321 firm year observations from 1963-1990. Basu estimates a pooled regression with dummies for the additional effects in various subperiods. We aggregate the coefficients to produce coefficients comparable to the Ely \& Waymire data regressions.

The Ball, Kothari \& Robin samples include 11,978 firm years for the 1985.90 period and 9,247 for the 1991.95 period. They estimate pooled regressions.

Xt is the firm earnings per share for year t, Pt-1 is the price at the beginning of year t, For the Basu data earnings are adjusted for market earnings.

Earnings is before extraordinary items for Ball, Kothari \& Robin

DRt is a dummy variable equal to 1 if $\mathrm{Rt}<0$ and zero otherwise.

$\mathrm{Rt}$ is the rate of return on the firm stock for year t. Ely \& Waymire measure the return over 16 months, fiscal year plus four months. ; Basu measures the return over

the 12 months beginning month four of fiscal year and adjusts for the market return; Ball, Kothari and Robin measure the return over the fiscal year

The test for conservatism is whether the slope coefficient for the last term is significantly positive. 